\title{
RETORNOS PRIVADOS AOS INVESTIMENTOS EM CAPITAL HUMANO: EVIDÊNCIAS DA PNAD-1995
}

\author{
LEONARdo Francisco FigueIREdO NETO
}

Engenheiro Agrônomo

Orientadora: Prof ${ }^{\underline{a}}$. Dr ${ }^{\mathrm{a}}$. ANA LÚCIA KASSOUf

Dissertação apresentada à Escola Superior de Agricultura "Luiz de Queiroz", Universidade de São Paulo, para obtenção do título de Mestre em Ciências. Área de Concentração: Economia Aplicada

PIRACICABA

Estado de São Paulo - Brasil

Outubro - 1997 
Dados Internacionais de Catalogação na Publicação (CIP) DIVISÃO DE BIBLIOTECA E DOCUMENTAÇÃO - Campus "Luiz de Queiroz"/USP

\section{Figueiredo Neto, Leonardo Francisco}

Retornos privados aos investimentos em capital humano : evidências da PNAD 1995. - - Piracicaba, 1997.

$97 \mathrm{p}$.

Dissertaçāo (mestrado) - - Escola Superior de Agricultura Luiz de Queiroz, 1997. Bibliografia.

1. Econometria 2. Educaçāo 3. Instrumentos 4. Recursos humanos I. Título

CDD 332.67

331.2592 


\title{
RETORNOS PRIVADOS AOS INVESTIMENTOS EM CAPITAL HUMANO: EVIDÊNCIAS DA PNAD-1995
}

\author{
LeONARdo Francisco Figueiredo Neto
}

Aprovada em: 27.11.1997

Comissão julgadora:

Prof. Dr. Carlos José Caetano Bacha

Prof . Dr ${ }^{\mathrm{a}}$. Angela Maria Cassavia Jorge Corrêa

Prof. Dr. João Gomes Martines Filho
ESALQ/USP

UNIMEP

ESALQ/USP

PROF. DR. CARLOS JOSÉ CAETANO BACHA

Substituindo o orientador 
$\grave{A}$

Maria Ester, minha mãe

Dedico 


\section{AGRADECIMENTOS}

À Prof ${ }^{\mathfrak{a}}$. Dr ${ }^{\mathrm{a}}$. Ana Lúcia Kassouf, pela orientação segura, apoio e sobretudo pela paciência neste trabalho. Aos senhores membros da banca examinadora, Prof. Dr. Carlos José Caetano Bacha, Prof. Dr. João Gomes Martines Filho e a Prof ${ }^{\text {e. }} \mathrm{Dr}^{\mathrm{a}}$. Angela Maria Cassavia Jorge Corrêa pelas pelas críticas e sugestões apresentadas que contribuíram para o aprimoramento do presente trabalho. Agradeço também ao Prof. Dr. Paulo Fernando Cidade de Araújo pelos comentários precisos que engrandeceram esta dissertação.

A Escola Superior de Agricultura "Luiz de Queiroz" e ao Departamento de Economia e Sociologia Rural, pela oportunidade de ampliar minha formação profissional.

Aos professores e funcionários do Departamento de Economia e Sociologia Rural, pela colaboração recebida, pelos ensinamentos e pela cortesia com que fui tratado.

Aos colegas do curso de Pós-Graduação pela inesquecível convivência, apoio e incentivo durante todo o curso.

À Coordenadoria de Aperfeiçoamento de Pessoal de Nível Superior (CAPES), pelo auxílio financeiro, durante o curso de Mestrado.

À todos que, direta ou indiretamente, tiveram alguma parcela de contribuição para realização deste trabalho.

À algumas pessoas especiais cujos nomes não são citados aqui, gostaria de expressar toda a minha gratidão, admiração e respeito. Espero que de alguma maneira, realmente possa retribuir ao menos um pouco, o que fizeram por mim, que certamente não será esquecido. 


\section{SUMÁRIO}

\section{Página}

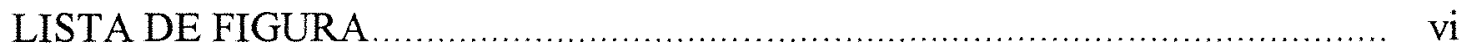

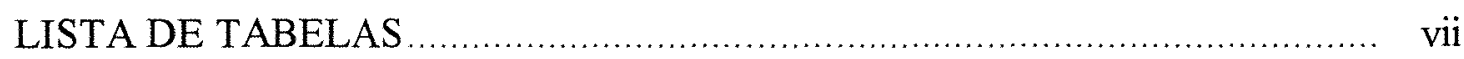

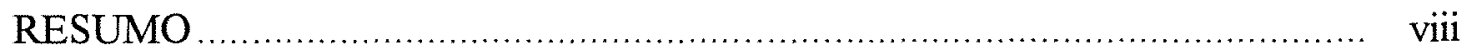

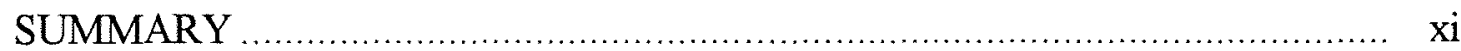

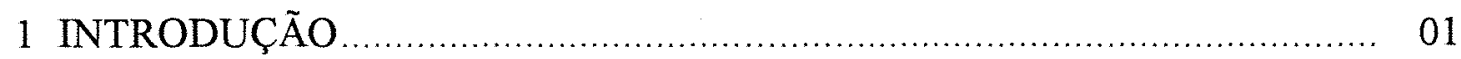

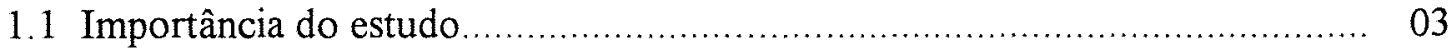

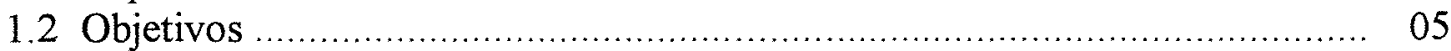

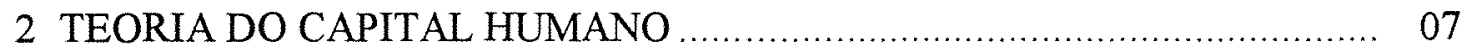

2.1 Investimento em Escolaridade ...................................................... 10

2.2 Investimento em Treinamento ...................................................... 12

2.3 Depreciação do Capital Humano ............................................... 16

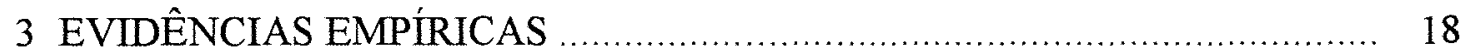

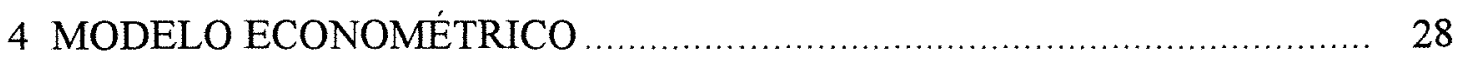

4.1 Algumas omissões de variáveis na equação de rendimentos ..................... 32

4.2 Procedimento de Heckman. ...................................................... 35

5 DADOS A SEREM UTILADOS …................................................. 38

5.1 Descrição das variáveis ............................................................ 39

5.2 Modelos a serem utilizados .................................................... 44

6 RESULTADOS DAS ESTIMATIVAS DO MODELO ECONOMÉTRICO ... 50

6.1 Participação no Mercado de Trabalho - Homens ................................. 51

6.2 Equação de Rendimentos - Homens ......................................... 52

6.3 Participação no Mercado de Trabalho - Mulheres ................................. 56

6.4 Equação de Rendimentos - Mulheres............................................... 60

6.5 Retornos aos Investimentos em Educação e Experiência.......................... 63

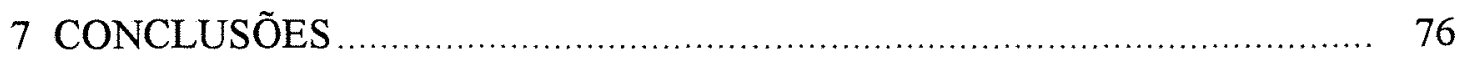

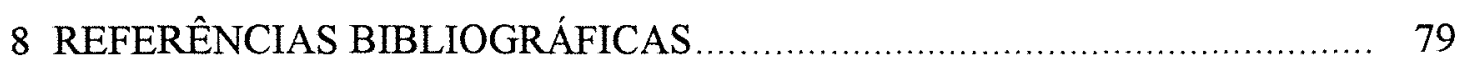

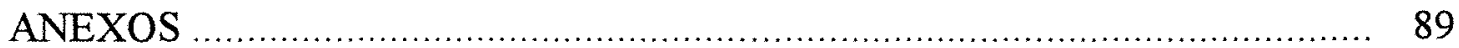




\section{LISTA DE FIGURA}

Página

1 Relação entre rendimentos e tempo de escolaridade 


\section{LISTA DE TABELAS}

Página

1 Diferencial de renda entre as população negra e parda e a branca 1990

2 Descrição das variáveis, médias e desvios padrão, para homens e mulheres participantes e não-participantes do mercado de trabalho

3 Descrição das variáveis, médias e desvios padrão, para homens e mulheres participantes do mercado de trabalho

4 Resultados da equação de participação no mercado - homens ..................... 51

5 Resultados da equação dos rendimentos - homens ................................. 53

6 Resultados da equação de participação no mercado de trabalho -

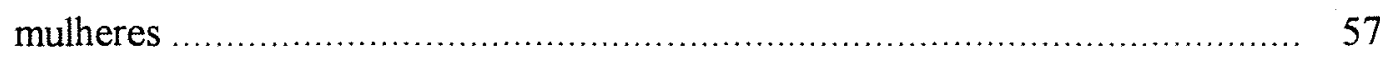

7 Resultados da equação de rendimentos - mulheres ............................... 61

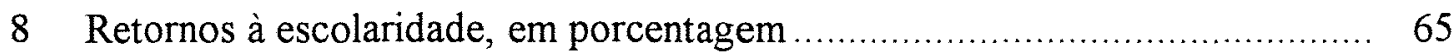

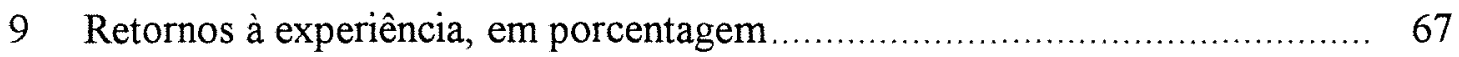

10 Retornos à escolaridade, em porcentagem (regiões) ........................ 70

11 Retornos à experiência, em porcentagem (regiões) .............................. 70

12 Retornos à escolaridade, em porcentagem (setor público e

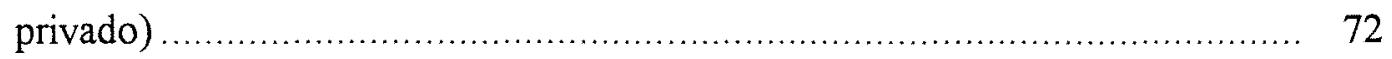

13 Retornos à experiência, em porcentagem (setor público e privado) ............... 73

14 Retornos à escolaridade, em porcentagem (sindicalizado e não sindicalizado)

15 Retornos à experiência, em porcentagem (sindicalizado e não sindicalizado) 


\title{
RETORNOS PRIVADOS AOS INVESTIMENTOS EM CAPITAL HUMANO: EVIDÊNCIAS DA PNAD -1995
}

\author{
Autor: LEONARDO FRANCISCO FIGUEIREDO NETO \\ Orientadora: Prof ${ }^{e}$. Dr ${ }^{\mathrm{a}}$. ANA LÚCIA KASSOUF
}

RESUMO

A teoria do capital humano trata os recursos humanos como investimentos e, como tal, deve ser entendida como uma teoria de capital, passível de ser avaliada em termos de taxa de retorno. O objetivo principal deste trabalho foi estimar a taxa de retorno privado à escolaridade (educação formal) e os investimentos realizados após o término do período escolar (experiência), a partir de dados da Pesquisa Nacional por Amostra de Domicílios (PNAD) de 1995.

Utilizou-se o procedimento de Heckman (1980) para obtenção de estimativas consistentes dos parâmetros, eliminando o problema da seletividade amostral. Esta metodologia consiste na estimação da variável lambda (inverso da razão de Mill), obtida a partir dos coeficientes estimados do modelo próbite da equação de participação no mercado de trabalho, e utilizada como variável exógena na equação de rendimentos.

As estimativas das equações de participação no mercado de trabalho e rendimentos foram obtidas separadamente para homens e mulheres. Posteriormente, de forma análoga, estimaram-se as equações para cada uma das regiões do país, para trabalhadores dos setores público e privado, assim como para trabalhadores sindicalizados e não-sindicalizados. As equações de participação no mercado de trabalho foram obtidas pelo método da máxima verossimilhança, utilizando o modelo próbite, em que a variável dependente assume valores 1 ou zero, indicando a participação ou não do indivíduo no mercado de trabalho, respectivamente. 
Educação e experiência têm efeito positivo sobre a probabilidade de participação dos indivíduos no mercado de trabalho. Como sugerido pela teoria do capital humano, a probabilidade de ingresso na força de trabalho eleva-se à medida que os indivíduos acumulam experiência no mercado de trabalho, declinando a partir de determinada idade, devido aos efeitos da depreciação e obsolescência do estoque de capital humano.

Para verificar este fato, utilizou-se o método dos mínimos quadrados ponderados para estimar as equações de rendimentos, usando-se o fator de expansão da amostra da PNAD (IBGE) como ponderador. Os resultados indicam que a utilização do procedimento de Heckman foi necessário para evitar a tendenciosidade nos coeficientes estimados, causados pela seletividade amostral. O acréscimo no número de anos de escolaridade e experiência aumenta os rendimentos dos trabalhadores. Como esperado, os perfis dos rendimentos dos trabalhadores apresentam forma côncava, pois, os rendimentos devem crescer após o ingresso no mercado de trabalho, provenientes dos ganhos de produtividade e acumulação de experiência e, a partir de determinada idade, devem cair, derivando do processo de depreciação e obsolescência do estoque de capital humano.

Os retornos à escolaridade e à experiência apresentaram valores positivos, e os primeiros mostraram-se sempre superiores aos segundos. Os homens apresentaram geralmente maiores retornos à experiência que as mulheres. Com relação aos retornos à escolaridade, observou-se que as mulheres sempre apresentaram maiores retornos.

A redução das disparidades nos rendimentos dos trabalhadores passa por uma alocação ótima dos recursos provenientes de políticas educacionais e, para tanto, é necessário conhecer o comportamento da distribuição e a participação da escolaridade como elemento determinante da renda do trabalho

Pelos resultados obtidos é possível ainda concluir, que a educação é um dos fatores mais relevantes para o aumento do capital humano assim como o treinamento. 
Numa economia moderna, que busca o melhor aproveitamento do capital físico e aumento da produtividade, é indispensável investir na melhora da qualificação da mão-deobra. 


\title{
PRIVATE RETURNS TO THE INVESTMENTS IN HUMAN CAPITAL: EVIDENCES FROM 1995 PNAD
}

\author{
Author: LEONARDO FRANCISCO FIGUEIREDO NETO \\ Adviser: $\operatorname{Prof}^{\mathfrak{e}} \mathrm{Dr}^{\mathrm{a}}$ ANA LUUCIA KASSOUF
}

SUMMARY

The theory of human capital treats human resources as investments and it should be understood as capital theory capable of being evaluated in terms of rate of return. The purpose of this study was to estimate private rate of return to investment in human capital, including formal education and post-school investments (experience). This study used Brazilian data from 1995 National Household Sample Surveys (PNAD).

The Heckman procedure was used to obtain consistent estimates of the parameters which eliminates problems of selectivity bias. This methodology consists of the estimation of the variable lambda which is the same as the inverse of Mill's ratio. It is obtained from the estimated coefficients of the probit model in the labor market participation equation and used as exogenous variable in the earning equation.

The estimation of the labor market participation and the earning equations was performed separately for men and women. Later, in a similar way, it analyzed the equations for each one of the country regions, for the public and private sectors, as well as for union and nonunion workers. The labor market participation equations were estimated through the method of maximum likelihood using the probit model, in which the dependent variable assumes value 1 or zero, indicating the participation or not participation in the labor market.

The results showed that education and experience have positive effect on the probability of the individuals' participation to the labor market. Most of the coefficients 
were statistically significant at the level of $10 \%$. As suggested by the human capital theory, the entrance probability in the labor market rises as the individuals accumulate experience and declines from a certain age.

The earning equations were estimated by generalized least squares, weighted by the sample expansion factor (PNAD). The results indicate that the use of the Heckman procedure was necessary to avoid the biased in the estimated coefficients. The increment in the number of years of education and experience increases workers' earnings. As expected, the profiles of workers' earnings present concave form, because earnings should grow after entering in the labor market. This gain come from the increase in the productivity and from the accumulation of experience, and starting from a certain age, they should drop because of the depreciation process and obsolescence of the stock of human capital.

The rate of returns to education and experience showed positive values and the prior were greater than the latter. Generally, men presented larger rate of returns to experience than women. With respect to the rate of returns to education, it was observed that women always presented larger returns than men.

This study showed that education as well as experience were two of the most important factors to the increase of the human capital. In a modern economy that looks for the best use of the physical capital and productivity increase, it is indispensable to invest in the improvement of labor qualification.

The reduction of the disparities in the workers' earnings goes through an optimal resource allocation that comes from educational policies. Thus, it is important to understand the behavior of the distribution and the participation of education as a decisive element of labor income. 


\section{INTRODUÇÃo}

Face à transição estrutural que a economia mundial está atravessando, onde o aumento da velocidade das descobertas tecnológicas e a busca por maior produtividade em todos os setores econômicos têm provocado uma crescente demanda por mão-deobra qualificada, destaca-se a importância definitiva de investir-se em capital humano para obter-se um melhor desempenho sócio-econômico das nações. O crescimento econômico está fundamentado no uso de sofisticadas tecnologias e, portanto, é indispensável investir em educação e treinamento, produzindo uma força de trabalho apta a lidar com essas novas tecnologias.

Recente relatório divulgado pelo Programa das Nações Unidas para o Desenvolvimento (PNUD), em 1996, indica que as deficiências sociais, especialmente na formação do capital humano, constituem um entrave ao desenvolvimento econômico. Este relatório compara o desempenho da Coréia do Sul, país em que $94 \%$ das crianças cursavam o curso primário em 1970, com o Paquistão, onde as matrículas atingiam somente $30 \%$ das crianças, sendo que os dois países possuíam o mesmo nível de renda per capita naquela data. Passados 25 anos, o primeiro cresceu três vezes mais que o segundo. Essa diferença de crescimento é atribuída ao maior investimento em capital humano por parte da Coréia do Sul.

Algumas teorias recentes sobre o estudo do desenvolvimento econômico, o chamado "modelo endógeno de crescimento", destacam a importância do conhecimento. Este é um dos fatores responsáveis pelo crescimento no longo prazo, anteriormente tratado como exógeno, podendo ter efeitos permanentes sobre a taxa de crescimento. Em 
seu trabalho, Lucas (1988) destaca os incentivos às empresas e/ou agentes não somente para ampliar negócios e investir em capital físico, como já preconizavam os modelos tradicionais, mas, também, a investir em capital humano e criar, investir ou adotar novas tecnologias, registrando a necessária complementariedade entre educação e capital físico. Nesta mesma vertente, Romer (1990) explora a conexão entre a educação e o desenvolvimento econômico, e particulariza a educação e suas conseqüências econômicas como elemento impulsionador do processo de crescimento econômico, sendo o capital humano "matéria-prima" estratégica neste processo.

O desempenho brasileiro é muito insatisfatório quando o assunto é investimento em capital humano, tornando a desigualdade de renda centro de renovadas atenções. Verifica-se que uma das causas primordiais da desigualdade de renda é a enorme diferença de nível de escolaridade dos indivíduos verificada no país. Estudos enfatizam que a relação entre a educação e a desigualdade de renda, segundo Barros \& Reis (1990), estão associados a dois fatores: i) os diferenciais de renda por nível educacional são muito maiores nos países em desenvolvimento do que nos desenvolvidos; e, ii) a própria educação é distribuída de forma mais desigual nos países em desenvolvimento.

Recente estudo do Instituto de Pesquisa Econômica Aplicada (IPEA) em $1996^{1}$ mostra que os $20 \%$ mais ricos possuem, em média, pouco mais de oito anos de escolarização, ao passo que os $20 \%$ mais pobres chegam a dois anos, existindo relação direta entre escolaridade e distribuição de renda. A parte mais rica da população tem renda 24 vezes superior à da mais pobre, enquanto na maioria dos países essa diferença é de aproximadamente 10 vezes. O mesmo estudo evidencia que a remuneração é fortemente influenciada pelo nível de escolaridade. Cada ano adicional de escolaridade é compensado com um aumento de $15 \%$ no salário, e aquele que alcançar o nível superior tem como prêmio $20 \%$ a mais relativos a cada ano passado na sala de aula. Outro estudo

\footnotetext{
${ }^{1}$ Educação e desigualdade de renda. O Estado de São Paulo. Economia e Negócios, São Paulo, 06 out. 1996. p. B-2.
} 
mostra que mesmo havendo uma redução do nível de analfabetismo ${ }^{2}, 15 \%$ dos trabalhadores são analfabetos e somente $25 \%$ dos que ingressam nas escolas conseguem terminar o segundo grau.

Ao estimar uma metafunção de produção agregada que relaciona a produção de cada estado do Brasil ao capital, trabalho, educação média no período de 1970 a 1980 , Lau et al. (1993) constataram que a elevação de 1 ano na média da escolaridade da força de trabalho poderia elevar o Produto Interno Bruto em aproximadamente 20\%, mostrando ser a escolaridade o fator chave para o desenvolvimento econômico.

A Organização Internacional do Trabalho (OIT) estudou o crescimento econômico dos países da América Latina no período de 1990 a $1994^{3}$, e comprovou que onde se investiu na recuperação salarial e na qualificação da mão-de-obra, obtiveram-se maiores exportações, produtividade do trabalho e, consequentemente, crescimento econômico. $\mathrm{O}$ investimento em capital humano proporciona melhor aproveitamento do capital fisico, elevando a produtividade e permitindo melhor remuneração pelas habilidades profissionais dos trabalhadores.

\subsection{Importância do estudo}

Estudos na área do capital humano indicam que trabalhadores com melhor nível de escolaridade e experiência tendem a receber, em média, maiores rendimentos. A proposta essencial da teoria do capital humano é tratar os recursos humanos como uma forma de capital, fruto de determinada decisão de investimento, e, como tal, pode ser avaliada em termos de taxa de retorno. A obtenção das estimativas de rentabilidade de

\footnotetext{
${ }^{2}$ Em 1950 a taxa de analfabetismo na população de 15 anos a mais era de 50,6\%, em 1995 essa taxa estava em 17,2\% . (Fonte: REVISTA EXAME. Investimento sem risco. 17 jul. 1996. ano 30, n.15, p. 4054).

${ }^{3}$ OIT liga salário mínimo a crescimento econômico. Folha de São Paulo, Dinheiro, São Paulo, 11 nov. 1995. p2-9.
} 
investimento em capital humano permite responder a algumas questões, tais como: qual o nível de educação formal que deve ser priorizado pelo governo na distribuição de recursos? Qual o setor econômico mais rentável? Há discriminação racial ou por gênero? Que região demonstra maior carência de capital humano? Conforme Psacharopoulos (1985), os valores das taxas de retorno também servem para compreender a demanda por certos níveis de escolaridade, e uma vez que a taxa de retorno é um valor que os indivíduos recebem pelo seu capital humano, ela pode ajudar a explicar a distribuição de renda pessoal

Parte dos trabalhos empíricos realizados sobre retornos à educação no Brasil, que utilizam modelos econométricos, somente trabalha com amostras de indivíduos que estão inseridos no mercado de trabalho [Senna (1976), Medeiros (1982), Macedo (1982), Leal \& Werlang (1991) e Ramos \& Vieira (1996)]. Entretanto, existe uma parcela razoável de adultos que não está engajada no mercado de trabalho. Os resultados obtidos poderiam estar gerando estimadores tendenciosos (viés de seletividade), devido a essa seletividade amostral existente, pois, somente são considerados os indivíduos efetivamente ocupados e com renda positiva. Dada a importância da educação no atual contexto econômico, uma estimativa atualizada de retorno à escolaridade, com indivíduos que participam ou não do mercado de trabalho, pode ajudar a explicar os diferenciais dos rendimentos existentes neste mercado. A redução das disparidades nos rendimentos dos trabalhadores passa por uma alocação ótima dos recursos provenientes de políticas educacionais e, para tanto, é necessário conhecer o comportamento da distribuição e a participação da educação como elemento determinante da renda do trabalho. O tema central deste trabalho é fazer uma investigação empírica, atualizada, da influência que a educação e os investimentos após a escola (experiência) exercem sobre os rendimentos dos trabalhadores, considerando a interação entre os determinantes da participação no mercado de trabalho e dos rendimentos. Para tanto, será utilizado um modelo econométrico baseado na teoria do capital humano, que permite uma desagregação dos dados, facilitando a análise e identificação das peculiaridades e características dos indivíduos e do mercado que afetam os seus rendimentos. 
Trabalhos semelhantes foram realizados por Tienfenthaler (1989), Kassouf (1994, 1996 e 1997) e Vieira (1997). Contudo esses trabalhos não analisaram as diferenças nos retornos à escolaridade e a experiência entre trabalhadores sindicalizados $\mathrm{e}$ não sindicalizados, setores de emprego (público ou privado) e regiões do país, que se efetua no presente estudo.

\subsection{Objetivos}

O objetivo principal deste trabalho é estimar a taxa de retorno privado ${ }^{4}$ aos investimentos em capital humano, incluindo tanto a educação formal (escolaridade) como os investimentos realizados após o término do período escolar (experiência) para todo o país. Para tanto são estimadas equações que explicitam os condicionantes que determinam os rendimentos, e aquelas que expliquem a participação das pessoas no mercado de trabalho.

Especificamente pretende-se, a partir das equações dos rendimentos estimadas, analisar o efeito da escolaridade e da experiência sobre a renda pessoal, em um nível de desagregação que proporcione diferenciar entre:

i) os homens e as mulheres;

ii) as regiões do país, captando as possíveis desigualdades existentes;

iii) trabalhadores filiados a sindicatos e não filiados; e,

4 De acordo Leal \& Werlang (1991), a taxa de retorno privado ou pessoal difere da taxa de retorno social, porque esta última inclui os impostos (do lado dos custos) e os custos (professores, manutenção e edificações). 
iv) trabalhadores do setor público e privado. 


\section{TEORIA DO CAPITAL HUMANO}

$\mathrm{Na}$ década de 60 , estudos mostraram que os dispêndios com educação deveriam ser considerados investimentos, tanto por parte das empresas, como pelo pais como um todo. Por seus estudos sobre a importância do capital humano no desenvolvimento dos países, economistas vencedores de Prêmio Nobel como Teodore W. Schultz e Gary Becker alteraram o enfoque tradicional, o que considerava os recursos naturais, as tecnologias e obras de infra-estrutura como fatores essenciais e de maior relevância ao progresso e, consequentemente, ao desenvolvimento econômico.

Conforme Crawford "embora o conceito de capital humano já fosse conhecido no século XVIII por Adam Smith e outros economistas, um trabalho sério sobre a teoria econômica do capital humano é algo bastante recente. A expressão capital humano apareceu pela primeira vez na literatura econômica em 1961 em um artigo intitulado Investindo em Capital Humano, publicado na American Economic Review escrito por Schultz" (Crawford, 1994, p. 17).

Schultz (1961) destaca a importância do capital humano, ampliando o conceito de capital para abranger o estoque de conhecimentos. Em outro trabalho, o mesmo autor enfatiza que o que é comumente chamado de consumo, na realidade, são investimentos em capital humano. Assim sendo, os gastos diretos com a escolaridade (educação formal), saúde e com a migração interna para conseguir vantagens oferecidas por melhores empregos são exemplos desse consumo, e o crescimento dos rendimentos do 
trabalho possui uma relação direta com este investimento (Schultz, 1971). As capacitações econômicas do homem são predominantemente alcançadas pelos investimentos citados, com exceção dos possiveis efeitos da habilidade natural dos indivíduos.

$\mathrm{Na}$ literatura disponível são mencionados, segundo Azevedo (1992) citando Blaug (1976), seis tipos de investimentos em capital humano: i) cuidado com a saúde; ii) educação adicional; iii) procura por trabalho; iv) resgate de informações, especialmente sobre oportunidades de trabalho; v) migração; e, vi) treinamento no trabalho.

Segundo Schultz (1971), o capital humano "é humano porque se acha configurado no homem e é capital porque é uma fonte de satisfações futuras, ou de futuros rendimentos, ou ambas as coisas" (Schultz, 1971, p.53). O capital humano referese às capacidades morais e de aquisição de conhecimentos dos seres humanos enquanto geradores de renda na economia, sendo uma riqueza capaz de gerar mais riqueza.

Ramos \& Vieira (1996) explicam que a teoria do capital humano parte da idéia de que as pessoas investem em si mesmas visando retornos futuros, que podem ser pecuniários ou não (satisfação pessoal). Governos também investem em educação para elevar o nível tecnológico da força de trabalho e, portanto, aumentar a produtividade dos trabalhadores e os rendimentos da sociedade como um todo. Tais investimentos podem ser feitos através de cuidados com a saúde, do tempo gasto procurando emprego com maiores salários, da aquisição de informações sobre oportunidade de trabalho, etc. As pessoas educam-se com o objetivo de ampliar o estoque de conhecimentos e mudar o seu potencial produtivo: quanto mais estudarem, maiores serão os seus conhecimentos e habilidades, maior será a produtividade e, consequentemente, mais elevados seus salários.

Conforme Psacharopoulos (1985), estimativas de rentabilidade de investimento em capital humano têm sido utilizadas para entender algumas questões, como a 
explicação das taxas de desenvolvimento econômico, a alocação ótima de recursos dentro da educação e entre os outros setores, o comportamento dos estudantes e suas familias como investidores e consumidores da educação e os determinantes da distribuição de renda.

A teoria do capital humano postula que a distribuição dos rendimentos do trabalho é função de treinamento e experiência [Byron \& Manaloto (1990)]. Se a renda de uma pessoa é vista como um produto de uma função de produção pessoal, os insumos são educação, experiência e horas trabalhadas. O nível de experiência das pessoas deve ser um capital complementar de melhoria para a educação. As diferentes quantidades de acumulação de capital humano podem ser consideradas, incontestavelmente, como uma das principais fontes da desigualdade de renda entre os indivíduos

Segundo Schuh \& Brandão (1990), educação e treinamento são atividades que adicionadas ao estoque de capital humano proporcionam desenvolvimento fisico e maiores conhecimentos. $\mathrm{O}$ estado de saúde e nutrição de uma população é outra parte importante do capital humano, pois também influencia a produtividade dos membros da sociedade. Os investimentos em seres humanos devem ser considerados como capitalizações que elevam o valor intrínseco dos indivíduos. Constatou-se que existe uma forte relação entre saúde, nutrição e educação, de um lado, e capacidade de trabalho, iniciativa e geração de renda, de outro ${ }^{5}$.

Mynt (1967), citado por Conceição (1995), afirma que os diversos trabalhos que estudam a questão do desenvolvimento têm enfatizado a importância do capital humano por diversas razões: i) a experiência dos países desenvolvidos sugere que a velocidade de crescimento econômico não pode ser explicada apenas em termos de aumentos quantitativos mensuráveis do capital fisico e do tamanho da população trabalhadora; ii) torna-se mais evidente que uma injeção maciça de capital em um país subdesenvolvido 
não iniciará, necessariamente, um processo de desenvolvimento sustentável, a menos que esse país já possua estrutura institucional e produtiva adequada e a mão-de-obra especializada necessária para absorver o novo capital e usá-lo de forma produtiva; e, iii) há ainda problemas operacionais causados pela falta de pessoas qualificadas para levar a frente os programas de desenvolvimento econômico.

Ramos (1991) examinou a evolução da distribuição dos salários no Brasil entre 1976 e 1985, com base na Pesquisa Nacional por Amostra de Domicílios (PNAD) da Fundação Instituto Brasileiro de Geografia e Estatística (IBGE), enfatizando, principalmente, a relação entre escolaridade e desigualdade salarial. $O$ trabalho foi realizado através da inspeção dos diferenciais de salário entre mão-de-obra qualificada e não-qualificada, ao longo do período caracterizado por um ciclo de expansão e outro de redução da atividade econômica. $\mathrm{O}$ autor destacou duas contribuições da educação para o bem-estar individual: permitir o acesso a maiores salários em um determinado instante de tempo, e reduzir a incerteza sobre o fluxo futuro de rendimentos do trabalho.

\subsection{Investimento em Escolaridade}

Pessoas investem em educação na expectativa de conseguir obter maiores ganhos no futuro. Ainda que envolva uma série de fatores, incluindo maiores rendimentos esperados, as pessoas buscam um maior nível educacional como instrumento de mudança do seu potencial produtivo e aumento de conhecimentos e habilidades.

Ao freqüentar a escola as pessoas estão sujeitas a custos, que podem incorrer de forma direta (taxas escolares e custos de materiais), como também indireta. No momento em que o individuo decide estudar, determinada parte do seu tempo, anteriormente

\footnotetext{
${ }^{5}$ Ver relatório sobre desenvolvimento humano no Brasil, 1996.
} 
destinado ao lazer ou trabalho, deverá ser realocada para a atividade educacional agora escolhida. Em ambos os casos, isso resultará um custo real para ele. Pressupondo que o lazer é algo desejável, e privar-se dele envolve um custo; o trabalho é recompensado com rendimentos e, se a educação significa perder trabalho, também significa renunciar rendimentos [Sheehan (1975)]. O valor associado ao trabalho e lazer perdido é um custo indireto da educação e é denominado custo de oportunidade. Quando a educação é compulsória, esse custo é quase nulo, tendo em vista que para o indivíduo inexiste algum rendimento alternativo a ser renunciado ${ }^{6}$. De acordo com Ramos \& Vieira $(1996$, p. 3):

\section{"a decisão de estudar é, grosso modo, comparada a um investimento: 0 indivíduo permanece na escola até o momento em que o retorno a um período adicional seja inferior ao do melhor investimento alternativo".}

Com as habilidades obtidas com a educação, admite-se que os indivíduos aumentem sua produtividade. Para Azevedo (1992), a escolaridade proporciona aos indivíduos um estoque de conhecimentos e habilidades, posicionando-os numa situação privilegiada, se comparados com aqueles que não obtiveram acesso à mesma educação. Isto confirma uma questão bem estabelecida no meio empresarial, de que pessoas com mais escolaridade podem ser treinadas a um menor custo, desde que já tenham mostrado habilidades para aprender.

Segundo Berndt (1991) os efeitos da escolaridade podem ser interpretados por três proposições a saber: i) do lado da oferta do mercado de trabalho: para induzir as

\footnotetext{
${ }^{6}$ De acordo com Senna (1976), é importante observar que com relação aos custos de oportunidade da educação primária, duas hipóteses diferentes podem ser geradas. A primeira é que não existem custos de oportunidade para os alunos de escola primária, devido a restrições legais relativas ao trabalho infantil. A outra hipótese é que apesar de haver limitações legais com respeito ao trabalho infantil, "uma grande parte delas trabalha, tanto dentro como fora da unidade familiar e, consequentemente, existem custos de oportunidade para freqüentar a escola" (Senna, 1976, p.167). Consideraremos no presente estudo que custos de oportunidade existem para os estudantes em todos os níveis de educação.
} 
pessoas a renunciar a rendimentos, incorrer em custos de materiais e taxas escolares, 0 trabalhador deve ser compensado com maiores rendimentos durante sua vida; ii) do lado da demanda do mercado de trabalho: para estar mais apto a receber maiores rendimentos, os trabalhadores com maior escolaridade devem ser mais produtivos do que seus colegas com menor número de anos de estudo, ou seja, o produto marginal dos trabalhadores deve aumentar com o nível de escolaridade; e, iii) no equilibrio de mercado: em equilíbrio competitivo de longo prazo, a relação entre escolaridade e rendimentos durante a vida deve ser de tal forma que a oferta e a demanda de trabalhadores em diferentes níveis de escolaridade são equiparadas e nenhum dos trabalhadores desejam alterar seu nível de escolaridade.

\subsection{Investimento em Treinamento}

Além da educação formal, o treinamento é também um tipo de investimento em capital humano, merecendo destaque na Teoria do Capital Humano.

Muitas habilidades requeridas pelo mercado de trabalho são adquiridas após os indivíduos deixarem a escola. Segundo Berndt (1991) essas habilidades podem ser obtidas através de sessões de treinamento formais e de aprendizagem estruturada até o mais informal "aprender fazendo".

De acordo com Blaug (1976), a principal constatação empírica feita por Mincer (1974) é a relação entre rendimentos, escolaridade e experiência de trabalho. Blaug (1976) reporta que as pessoas realizam investimentos individuais em capital humano, após a educação escolar, trocando rendimentos correntes por treinamento no trabalho, de forma que os retornos aos investimentos são inicialmente negativos, quando os rendimentos que são renunciados superam os retornos líquidos alcançados. Num 
determinado momento, os retornos líquidos acumulados igualam os rendimentos renunciados, e os retornos aos investimentos pós-escola passam a ser positivos. Ao ponto onde os retornos líquidos de capital humano passam de negativos para positivos, Mincer deu o nome de "ponto de superação". Este autor também destaca o "on-the-job-training" (mistura de "learning-by-doing"7 e "doing-under-supervision") considerando-o também como um investimento em capital humano

Existem duas formas de treinamento, propostas por Becker (1964), amplamente aceitas para analisar as implicações do treinamento de pessoal: treinamento genérico, o qual proporciona um aumento da produtividade do trabalhador, e essas habilidades adquiridas podem ser amplamente usufruidas por qualquer empresa; e treinamento especifico, o qual aumenta a produtividade do trabalhador somente em determinada(s) tarefa(s), podendo apenas usufruir desse treinamento, a empresa que o proporcionou.

A expressão investimento pós-escola, também chamada de investimento em treinamento, possui um significado extenso. Compreendendo o treinamento formal e o treinamento informal, assim como o chamado "on the job training". Como todo investimento, é importante observar que os indivíduos incorrem em custos para apropriar-se das oportunidades de aprendizado. De acordo com Becker (1964): "produtividade pode ser aumentada apenas a um custo, pois de outra forma existiria uma demanda ilimitada por treinamento".

Algumas questões interessantes surgem quando se analisam os custos e os beneficios desses investimentos, a partir das peculiaridades do treinamento genérico e específico. Berndt (1991) explica que se o mercado de trabalho for competitivo, as empresas não estão dispostas a arcar com os custos do treinamento genérico, pois o trabalhador que recebe este treinamento, pago pela empresa, poderia mudar de emprego

${ }^{7}$ Caracteriza a influência da idade e experiência no trabalho no desenvolvimento de habilidades profissionais (Medeiros, 1982). 
após a conclusão do treinamento, e as empresas não teriam como obter algum retorno sobre este investimento. Normalmente, o trabalhador assume, totalmente ou em parte, o custo do treinamento na forma de redução salarial durante o período de treinamento, e os trabalhadores estão propensos a assumir estes custos, visto que o treinamento proporciona um aumento na produtividade, podendo refletir futuramente em maiores salários. Este fato é corroborado por Alves \& Soares (1996), ao destacar que dada a dinâmica das relações de trabalho e a estrutura de mercado em que a empresa está inserida, os custos referentes à acumulação de capital humano via treinamento podem gerar desde uma atitude descompromissada com a formação profissional de seus empregados, até o surgimento de acordo e práticas que objetivam à divisão do custo de treinamento entre empresa e trabalhador. Normalmente, os setores que apresentam alta rotatividade são exatamente aqueles em que trabalhadores e empresas tendem a subinvestir em capital humano.

No treinamento especifico, por outro lado, o trabalhador não poderá utilizar este investimento em outra empresa, garantindo a continuidade no emprego e o benefício à firma. Sob a ótica do empregador, depois de treinado o empregado, este torna-se um ativo de alta especificidade ${ }^{8}$. Se existir a possibilidade do trabalhador mudar de emprego, e as empresas estiverem dispostas a oferecer treinamentos específicos para seus trabalhadores, querendo desfrutar dos retornos deste investimento, elas devem procurar opções e incentivos para que o trabalhador não se desligue da empresa, tal como remunerar melhor o trabalhador, atenuando o custo da rotatividade no emprego.

Entretanto, os investimentos após a escola apresentam um problema crítico com relação à quase total falta de informação sobre os seus custos. Senna (1976) afirma que

\footnotetext{
${ }^{8}$ Williamsom (1991, p. 281) explica que a especificidade de um ativo pode ser considerada como "o grau segundo o qual um ativo pode ser realocado para usos alternativos, sem prejuizo do seu valor produtivo". $\mathrm{O}$ autor coloca que a especificidade humana diz respeito à qualidade e grau de substitubilidade dos recursos humanos disponíveis. Quanto maior a qualidade e menor o grau de substitubilidade, maior será sua especificidade.
} 
em casos de programas formais de treinamento de mão-de-obra, identificam-se normalmente dois tipos de custos: a) os custos para os trabalhadores que recebem treinamento, que em geral têm de renunciar a parte dos seus rendimentos para participar desses programas; e, b) os custos para as empresas que proporcionam o treinamento, sob a forma de remuneração aos instrutores, depreciação de máquinas e equipamentos e, muitas vezes, financiamento de parte dos custos indiretos (rendimentos renunciados) dos trabalhadores que recebem treinamento. Em ambos os casos, as disponibilidades de informações são, normalmente, quase inexistentes.

$\mathrm{Na}$ realidade, esses dois tipos de treinamento (genérico e específico) muitas vezes podem não ser verificados. Berndt (1991) afirma que investimentos em trabalhadores consiste numa mistura desses dois tipos, e pessoas com maior escolaridade tendem a receber, em média, uma quantidade maior de treinamento, facilitando ainda mais o acúmulo de capital humano.

Conforme Barros \& Mendonça (1995), para melhor compreensão entre a relação experiência e produtividade, é essencial distinguir entre dois tipos de experiência: a no mercado de trabalho e a no emprego atual. O tempo de experiência no emprego atual tende a elevar a produtividade do trabalhador, pois parte deste tempo é aproveitado para desenvolver e/ou aperfeiçoar suas habilidades. As habilidades adquiridas por um trabalhador são em certa medida específicas ao emprego atual e, consequentemente, têm impacto maior sobre a produtividade neste emprego do que em outros, levando a que o tempo no emprego atual tenha maior influência sobre a produtividade e o rendimento do que a experiência no mercado de trabalho.

Estes mesmos autores enfatizam que existem pelo menos três explicações alternativas relacionando rendimentos com experiência no emprego atual que possuem implicações radicalmente distintas: i) o salário pode crescer com o tempo de 
permanência na empresa, simplesmente devido a regras internas desta que pouco ou nada estão relacionadas com o crescimento da produtividade; ii) o salário pode crescer com o tempo de permanência na empresa porque os trabalhadores que melhor se adequam às funções da firma permanecem, enquanto aqueles que não se adaptam pedem demissão ou são demitidos; e, iii) o tempo de permanência na empresa de fato eleva a produtividade do trabalhador, uma vez que parte desse tempo é utilizado pelo trabalhador para desenvolver ou aprimorar suas habilidades.

\subsection{Depreciação do Capital Humano}

Assim como o capital físico, o capital humano pode se depreciar. Tal depreciação pode acontecer devido à interrupção no trabalho ou ao desemprego, à obsolescência, e também com o decorrer do tempo, pois à medida em que o trabalhador envelhece, algumas habilidades se depreciam, exigindo um número maior de horas para realizar determinadas tarefas.

Conforme assinalam Avila et al. (1983), existem dois processos de obsolescência: o do capital humano intelectual e o do capital humano físico. Quanto à depreciação do capital humano, Alves (1980) considera duas dimensões: uma absoluta e outra relativa. A absoluta está relacionada à perda do conhecimento ou esquecimento, ao passo que a depreciação relativa corresponde à paralisação ou pequeno progresso em relação ao mundo científico e tecnológico, que se desenvolve com muita rapidez.

Os estudos realizados sobre a importância da experiência no mercado de trabalho mostram uma relação entre experiência e rendimentos com a forma côncava (Uinvertido), denotando que os rendimentos aumentam inicialmente com a experiência a taxas decrescentes. A partir de determinado ponto, os rendimentos tendem a decrescer 
com o nivel de experiência do trabalhador. Isto evidencia um processo de obsolescência e depreciação da qualificação do trabalhador. 


\section{EVIDÊNCIAS EMPÍRICAS}

Existem vários trabalhos que enfatizam o papel da escolaridade como um dos principais determinantes dos rendimentos, utilizando algumas metodologias distintas, mas obtendo alguns resultados em comum. Inicialmente, serão expostos os trabalhos feitos em outros países e, posteriormente os realizados no Brasil.

Anderson (1980) analisou a taxa de retorno à escolaridade em El Salvador, com base na equação dos rendimentos, a partir de uma amostra de 33.000 indivíduos participantes do mercado de trabalho. Quando somente escolaridade e experiência foram as variáveis explicativas, a taxa de retorno estimada foi $19 \%$. Adicionando mais duas variáveis [experiência ao quadrado e um termo de interação (escolaridade x experiência)] do lado direito da equação, o valor da taxa de retorno cai para $15 \%$.

Avaliando os retornos à escolaridade para assalariados e autônomos (selfemployed) em Teerã (Irã), Henderson (1983) mostrou que os trabalhadores assalariados apresentam taxa de retorno maior $(11,5 \%)$ do que a dos autônomos $(7,3 \%)$; este valor reflete o fato de que os assalariados apresentam um nível de escolaridade mais elevado (4,8 anos contra 2,5 anos). Ao comparar os trabalhadores autônomos e assalariados com ocupações similares, as taxas de retorno foram praticamente idênticas $(11,6 \%$ e $11,5 \%$, respectivamente). 
Psacharopoulos (1985) procurou evidências de retorno ao investimento à escolaridade a partir de estudos realizados em mais de 60 países. Além de uma revisão das metodologias, e das controvérsias, ele relaciona mais de 500 estimativas de taxa de retorno por país, método de estimativa, nível e tipo de escolaridade (ensino normal ou técnico), gênero, setor de emprego (público ou privado) e ano, e sintetiza as taxas médias. Os resultados encontrados mostraram que os retornos à escolaridade são maiores para o ensino básico, para a educação da mulher e em países com menor renda per capita, e que as taxas de retorno têm diminuído com o passar do tempo.

Gaag \& Vijverberg (1989) estimaram a taxa de retorno à escolaridade na Costa do Marfim, com base nos trabalhadores assalariados dos setores urbano e rural, utilizando a escolaridade e a experiência como variáveis explicativas. A taxa de retorno por ano adicional de estudo foi aproximadamente $20 \%$ para quem freqüentou a escola por doze anos, bastante alta se comparada com outros estudos, e a taxa de retorno para quem possuía diploma universitário $(22 \%)$ mostrou-se bem maior quando comparada à das pessoas que permaneceram somente seis anos na escola (12\%).

Estudando os retornos à escolaridade na China, Byron \& Manaloto (1990) concluíram que esses estes são muito baixos (cerca de 4\%), mas ainda maiores do que os retornos a experiência. As mulheres no presente estudo, com mesmo nível de escolaridade e experiência, tiveram os rendimentos aproximadamente $9 \%$ abaixo dos observados para os homens.

Psacharopoulos \& Velez (1992) estudaram a taxa de retorno à escolaridade na Colômbia, com dados referentes a trabalhadores assalariados, autônomos e micro empresários, coletados no ano de 1988, de todos os setores econômicos e em empresas de diversos tamanhos, perfazendo um total de 2.087 indivíduos. Baseado na metodologia proposta por Mincer (1974), o valor estimado para a taxa de retorno à escolaridade foi de 
$10,5 \%$. Os autores fizeram uma análise da evolução das taxas de retorno à escolaridade de 1965 a 1988 (a Colômbia é um dos poucos países que possuem uma série histórica de taxas de retorno), e observaram que nesse período as taxas de retorno caíram aproximadamente $39 \%$ (de $17,3 \%$ em 1965 para $10,5 \%$ em 1988), sendo que os dotes educacionais da força de trabalho urbana cresceram bastante (de 1975 a 1986, as matrículas no segundo grau e na universidade cresceram $63,6 \%$ e $128,5 \%$, respectivamente).

Pesquisando a força de trabalho (homens de 18 a 64 anos) na Faixa de Gaza e “West Bank", entre 1981 e 1991, Angrist (1995) mostrou que as variações nos retornos à escolaridade entre diferentes grupos de escolaridade caíram muito no período analisado. Esta redução esboçada (aproximadamente 18\% para os judeus e 50\% para os não-judeus) está associada ao enorme aumento da escolaridade da força de trabalho palestina ( $7 \%$ da força de trabalho palestina em 1981 possuía 13 anos ou mais de escolaridade; já em 1991, essa porcentagem subiu para 12\%). Desde que os retornos à escolaridade para os judeus nascidos em Israel permaneceram estáveis, o declínio nas taxas de retorno para Palestinos é consistente com a idéia de que o retorno à escolaridade neste local foi amplamente determinado pelas forças de oferta e demanda em um mercado segmentado por trabalhos especializados.

Utilizando dados de vários países sobre a renda real por trabalhador e a escolaridade média da força de trabalho, Ram (1996) estimou, através do modelo de escolaridade simples proposto por Mincer (1974), as taxas de retorno à escolaridade para toda a amostra e várias outras com diferentes níveis de desenvolvimento econômico, tentando avaliar se o dinamismo econômico tem efeito positivo sobre tais retornos. Os resultados do trabalho podem ser sintetizados nos seguintes itens: i) o modelo simples utilizado é adequado, mostrando ser melhor do que os formulados em outros estudos que usam equações com grande número de variáveis explicativas; ii) a taxa de retorno à 
escolaridade global encontrada é de aproximadamente $13 \%$, consistente em comparação com o número encontrado por outros pesquisadores; iii) a taxa de retorno à escolaridade é mais baixa em países desenvolvidos, se comparada à dos países menos desenvolvidos, o que é também consistente com outros estudos; iv) a taxa de retorno estimada para os países em desenvolvimento, de baixa renda, mostra-se menor do que nos países de renda média; v) dinamismo econômico parece aumentar o retorno à escolaridade; e, vi) algumas investigações preliminares apontam que os modelos multivariados utilizados para comparar as estimativas de taxa de retorno entre países podem não ser muito afetados pela inclusão ou exclusão da variável renda-por-trabalhador .

Estudando o retorno à escolaridade dos trabalhadores urbanos no Brasil em diversas atividades econômicas (industrial, comércio e de serviços), totalizando mais de 265.000 observações referente ao ano de 1970, Senna (1976) utilizou a equação de rendimentos (Mincer, 1974) para estimar a taxa de retorno à escolaridade. O valor encontrado foi, aproximadamente, $12,5 \%$, e a escolaridade explicava cerca de $34 \%$ da desigualdade salarial. Este resultado foi obtido considerando somente a escolaridade como variável explicativa para os rendimentos. Ao adicionar na equação de regressão a experiência como variável explicativa, os coeficientes indicaram aumento na taxa de retorno à escolaridade para $14 \%$ e a taxa de retorno à experiência variou de 10 a $30 \%$ (escolaridade e experiência explicavam $44 \%$ da desigualdade salarial).

Ao analisar as diferenças de salário entre profissionais de processamento eletrônico de dados (abrangendo 34.557 indivíduos) no Brasil, Macedo (1982) constatou alto grau de correlação positiva entre salários e escolaridade. A taxa média de retorno à escolaridade formal foi estimada em cerca de 19,1\% (escolaridade explicando $29,4 \%$ do total da variância dos logaritmos dos salários individuais). A inclusão da segunda variável explicativa (experiência) na equação reduz a taxa média de retorno à escolaridade para $17,4 \%$, mas aumenta o poder de explicação do modelo para $44,4 \%$. 
Segundo o autor, esse bom nível de ajustamento é consistente com o contexto do rápido crescimento do setor combinado a um baixo estoque de capital humano.

Considerando alguns modelos representativos das diferenças de rendimentos, Medeiros (1982) tentou fornecer evidências empíricas que mostram o alcance e as limitações da teoria do capital humano. A partir de dados da PNAD de 1973 (selecionaram-se os indivíduos que trabalhavam quarenta horas ou mais por semana), este autor testou a hipótese de que o papel da escolaridade é superestimado na explicação da diferença dos rendimentos e concluiu que uma sensivel desigualdade nos rendimentos persiste mesmo em grupos semelhantes em termos de escolaridade (indivíduos educacionalmente homogêneos permanecem economicamente heterogêneos). Outra conclusão do autor é que variáveis extra-educacionais como sexo, posição no emprego, região, idade e classe social do pai influenciam também os rendimentos de forma significativa e persistente.

Analisando a evolução da relação entre educação e desigualdade salarial nas regiões metropolitanas brasileiras, no periodo de 1976 a 1986, o trabalho de Barros \& Reis (1990) mostrou que aproximadamente $50 \%$ da desigualdade dos salários são explicados pela escolaridade, e esta desigualdade é menor nas regiões metropolitanas do Sul e Sudeste do que naquelas localizadas no Nordeste, onde o conteúdo educacional da força de trabalho é menor.

Lam \& Levinson (1990), utilizando dados da Pesquisa Nacional por Amostras de Domicílio (PNAD-1985), analisaram os perfis de desigualdade dos rendimentos por idade e experiência para grupos de homens brasileiros e compararam com os perfis norte-americanos, decompondo-os através de um modelo de capital humano [equação de logaritmos dos rendimentos proposta por Mincer (1974)]. Concluem que a desigualdade na distribuição da educação é cerca de 4 vezes maior no Brasil do que nos Estados 
Unidos, e que a taxa de retorno à escolaridade é aproximadamente de $15 \%$ por ano adicional de estudo, ao passo que, nos Estados Unidos, esta taxa de retorno varia de 9 a $11 \%$ para grupos de mesma idade. A escolaridade explica $50 \%$ da variação dos rendimentos dos homens de 30 a 33 anos de idade no Brasil. Examinando os grupos de homens norte-americanos com a mesma idade, constata-se que a escolaridade consegue explicar menos que $10 \%$ da variação dos rendimentos. Este estudo reforça a idéia de que as mudanças nos níveis de escolaridade desempenham papel essencial na explicação dos perfis de desigualdade de renda nos dois países.

Também tendo por base os dados da PNAD, Leal \& Werlang (1991) calcularam as taxas de retorno à escolaridade, no período 1976/89, de acordo a metodologia desenvolvida por Mincer (1974). Com uma amostra composta por homens das regiões metropolitanas (exceto Brasília), entre 25 e 50 anos de idade, com jornada de trabalho igual ou superior a 20 horas semanais e renda positiva. Verificaram que a taxa é bastante elevada, aproximadamente $16 \%$ ao ano. Estes autores também citaram vários trabalhos que estimaram a taxa de retorno social da educação no Brasil, entre outros Langoni $(1970,1972 \text { e } 1974)^{9}$, Castro (1971 a e 1973) ${ }^{10}$, Levy (1970) e Gibbon (1975) ${ }^{11}$, em que se calculam os custos da educação (custos de edificação e custos de manutenção e pagamento dos professores) e seus benefícios (a renda bruta individual). Com base nestes dados, monta-se um fluxo de caixa e se chega à taxa interna de retorno [com base em Schultz (1963) e Becker (1964)]. Existem dois problemas, porém, com estes cálculos: a) subestimam a taxa real de retorno social, pois, não consideram a grande externalidade positiva da educação; e, b) os resultados são muito sensíveis, porque

\footnotetext{
${ }^{9} \mathrm{O}$ autor trabalhou com dados do Censo Demográfico do IBGE (1960) e da PNAD (1969). A taxa de retorno estimada para o ano de 1969 foi $28 \%$, e o curso primário apresentou a rentabilidade mais elevada (48\% em 1960 e $32 \%$ em 1969).

${ }^{10} \mathrm{Fez}$ uma análise comparativa de três estudos sobre a rentabilidade dos investimentos em educação no Brasil: o de Itabirito e Belo Horizonte, o de São Paulo, e o referente a todo o Brasil.

${ }^{11}$ Estimou taxas de retorno dos investimentos em educação utilizando dados de rendas médias desagregadas por idade, nivel de educação, setor de atividade, sexo e região.
} 
existem muitas maneiras (nenhuma completamente correta ou incorreta) de serem apropriados os custos, com isso, as taxas de retorno variam muito.

Examinando a natureza da relação entre educação e salários no Brasil, Ramos \& Vieira (1996) estimaram os retornos à escolaridade diferenciados por níveis completos de escolaridade (analfabetos, educação primária, secundária e universitária) e anos de escolaridade, com base na equação dos rendimentos. A partir das PNADs de 1976, 1981, 1985 e 1990, e o universo de análise constituído pelos homens ( 25 a 65 anos) ocupados nas regiões urbanas, que trabalham mais de 20 horas no trabalho principal e que sejam assalariados. Observaram que os retornos à escolaridade são, na maioria das vezes, mais elevados para os grupos de maior escolaridade, principalmente no caso de educação superior, onde o aumento médio de salários associado a cada ano adicional é de aproximadamente $20 \%$. Também enfatizaram a existência de um prêmio adicional por completar um estágio do processo educacional de considerável magnitude na maioria dos casos, sendo particularmente elevada para quem conclui o curso superior, indicando que a aquisição de escolaridade no Brasil funciona tanto para elevar a produtividade dos indivíduos, através do incremento de seu capital humano, quanto como elemento de sinalização para o mercado de dotação de tributos que influencia diretamente essa produtividade.

Observa-se que a maior parte dos trabalhos empíricos acima citados que investigam as taxas de retorno aos investimentos em escolaridade e experiência, utilizaram dados referentes aos indivíduos que estão inseridos no mercado de trabalho. Ao considerar, na amostra somente os indivíduos que participam do mercado de trabalho (ou seja, que possuem rendimentos), isso poderia causar viés nos coeficientes devido a seletividade amostral existente. Trabalhos mais recentes tentam obter estimativas consistentes dos parâmetros nas equações de rendimentos, incorporando a interação 
entre os determinantes da decisão de participação no mercado de trabalho e rendimentos (Procedimento de Heckman), incluindo os adultos que dele não estão participando.

Estimando os efeitos do capital humano sobre os rendimentos $\mathrm{e}$ os determinantes da oferta de trabalho em Sri Lanka, Sahn \& Alderman (1988) utilizaram o procedimento de Heckman para corrigir o viés da amostra de seletividade, e apontam que os rendimentos são afetados pela educação e experiência, e que a taxa de retorno à escolaridade para quem completou todo o ciclo escolar, mas que ainda não cursa a universidade, apresenta notável diferença. As mulheres sempre apresentaram taxa de retorno maior que a dos homens, tanto no meio rural $(14,4 \%$ contra $7,4 \%)$, quanto no urbano $(35,5 \%$ contra $12,6 \%)$. Observou-se, também, que o setor rural sempre apresentou taxas de retorno à escolaridade menores, o que pode explicar em parte a grande migração para o setor urbano, segundo os autores. Por outro lado, aqueles que possuem diploma universitário não são aparentemente discriminados pelo sexo, pois, as taxas de retorno para o setor urbano ( $16,1 \%$ para os homens e $15,1 \%$ para as mulheres) e rural $(13,4 \%$ e $14,3 \%)$ apresentaram valores aproximados.

Examinando a participação no mercado de trabalho das mulheres casadas no Japão, Hill (1989) empregou o procedimento de Heckman para estimativa da equação de rendimentos. Concluindo que cada ano adicional de escolaridade e de experiência no mercado de trabalho é recompensado com aumento, em torno de 6 e 3\%, respectivamente, nos rendimentos (considerando o mercado formal).

Analisando a participação das mulheres no mercado de trabalho no Brasil, Tiefenthaler (1989) estimou retornos à escolaridade para mulheres solteiras e casadas nos setores formal e informal, e sem vínculo empregatício (autônomo). Também fez uso do procedimento de Heckman, ressaltando que esta metodologia corrige o viés ocasionado pela amostra de seletividade. Os resultados indicam que, quanto maior o nível de escolaridade e experiência das mulheres, a probabilidade de participarem do 
mercado de trabalho aumenta. Entretanto, quanto maior sua renda não-salarial e a renda do marido, menores são as probabilidades de engajamento no mercado de trabalho. Com relação às taxas de retorno à escolaridade, os resultados podem ser sumarizados nos seguintes itens: i) as mulheres casadas e solteiras que trabalham no setor informal apresentaram as maiores taxas de retorno; ii) as taxas de retorno mais baixas estimadas foram para as trabalhadoras do setor formal com baixo nível de escolaridade (4 anos); iii) as taxas de retorno estimadas sempre mostraram valores superiores a $10 \%$; iv) as mulheres com curso superior completo apresentaram os maiores retornos à escolaridade em todos os setores do mercado de trabalho (formal, informal e autônomo).

Kassouf (1994) comparou o procedimento de Heckman a um método de estimação tradicional (mínimos quadrados ordinários) da equação de rendimentos. Considerou-se na amostra, homens e mulheres de 16 a 71 anos de idade, utilizando como base de dados a Pesquisa Nacional sobre Saúde e Nutrição de 1989. Os resultados mostraram que, ao considerar somente os indivíduos que são participantes do mercado de trabalho, há tendenciosidade nas estimativas dos parâmetros, tanto para os trabalhadores do sexo masculino (tendenciosidade positiva em valor absoluto) quanto do sexo feminino (tendenciosidade negativa em valor absoluto).

Estudando os retornos à escolaridade e experiência para trabalhadores dos setores rural e urbano no Brasil, também a partir de dados da Pesquisa Nacional sobre Saúde e Nutrição referente ao ano de 1989, Kassouf (1996) utilizou a metodologia proposta por Heckman para estimar os coeficientes da equação de rendimentos, e, posteriormente, calcular esses retornos. Os resultados apresentaram sempre retornos à escolaridade superiores aos da experiência, e estes foram maiores no setor urbano, comparados aos do setor rural. Além disso, os retornos à escolaridade para mulheres superaram os dos homens em ambos os setores. 
Com base em dados da PNAD-1995, Vieira (1997) estudou os retornos à escolaridade e à experiência entre empregadores, trabalhadores do setor formal e informal. Utilizou a metodologia proposta por Heckman para corrigir o viés causado pela seletividade amostral. Os retornos à escolaridade apresentaram-se sempre maiores para as mulheres em relação aos homens. Os trabalhadores do setor formal, quando comparados com os empregadores e os trabalhadores do setor informal, mostraram maiores retornos à escolaridade. Os retornos à experiência estimados sempre foram mais baixos que os retornos à escolaridade para todas as categorias analisadas.

Também comparando os retornos à escolaridade e experiência entre os setores formal e informal do mercado de trabalho, Kassouf (1997), utilizando dados da Pesquisa Nacional sobre Saúde e Nutrição de 1989, analisou os determinantes da participação no mercado de trabalho e dos rendimentos, efetuando comparações entre os dois setores e entre homens e mulheres. A análise mostrou, entre outras conclusões, que: i) os trabalhadores do setor formal recebem maiores rendimentos que os do setor informal; ii) os trabalhadores (em ambos os setores) residentes nas regiões Norte e Nordeste recebem menores rendimentos, se comparados com o resto do país; iii) o setor formal apresentou maiores retornos à escolaridade e experiência se comparados ao setor informal; e, iv) os retornos à escolaridade foram maiores para os homens no setor formal, enquanto que no setor informal esses foram maiores para as mulheres. 


\section{MODELO ECONOMÉTRICO ${ }^{12}$}

A maior parte dos trabalhos econométricos sobre a determinação dos rendimentos é baseada num modelo de capital humano proposto por Mincer (1974), conhecido por modelo de escolaridade (equação dos rendimentos), que discorre sobre a distribuição da renda do trabalho,

$$
\ln Y_{i}=f\left(S_{i}, E_{i}, Z_{i}\right)+u_{i} \quad i=1, \ldots, n
$$

onde $Y_{i}$ é o rendimento ou salário do $i$-ésimo indivíduo, $S_{i}$ é o número de anos de escolaridade do indivíduo $i, E_{i}$ significa anos de experiência no mercado de trabalho (investimentos pós-escola), $Z_{i}$ são outros fatores que afetam os rendimentos como: raça, gênero, setor econômico, região, entre outros, e $u_{i}$ representa erros não correlacionados com outros determinantes dos rendimentos observados. Usualmente, assume-se que $u_{i}$ é normalmente distribuído com média zero e variância constante.

A proposta fundamental deste modelo é considerar o período de educação formal como o fator determinante das diferenças de rendimentos entre os indivíduos. Ao investirem em educação formal, os indivíduos retardam o ingresso no mercado de trabalho. Essa decisão em permanecer (ou ingressar) na escola, ao invés de entrar no mercado de trabalho, leva a uma renúncia de renda (o indivíduo deixa de ganhar uma certa renda que a sua qualificação profissional permitiria obter no mercado de trabalho), representando um custo para o indivíduo. Este custo é comumente chamado de custo de

\footnotetext{
${ }^{12}$ Ver Mincer (1974), Senna (1976) e Berndt (1991)
} 
oportunidade ou custo indireto da educação, constituindo um elemento representativo dos custos totais da educação. Pressupõe-se que os indivíduos entram no mercado de trabalho logo após o término do período de educação formal (isto é, assim que pare de freqüentar a escola), e que seu estoque de capital humano não aumente após o ingresso no mercado de trabalho (hipótese que será abandonada a seguir, neste trabalho). E considera-se, também, que os rendimentos dos indivíduos permaneçam constantes ao longo de toda a sua vida útil (hipótese que também será abandonada posteriormente)

De acordo essas hipóteses, podemos derivar uma representação diagramática, que relaciona rendimentos e periodo de tempo (Figura 1).

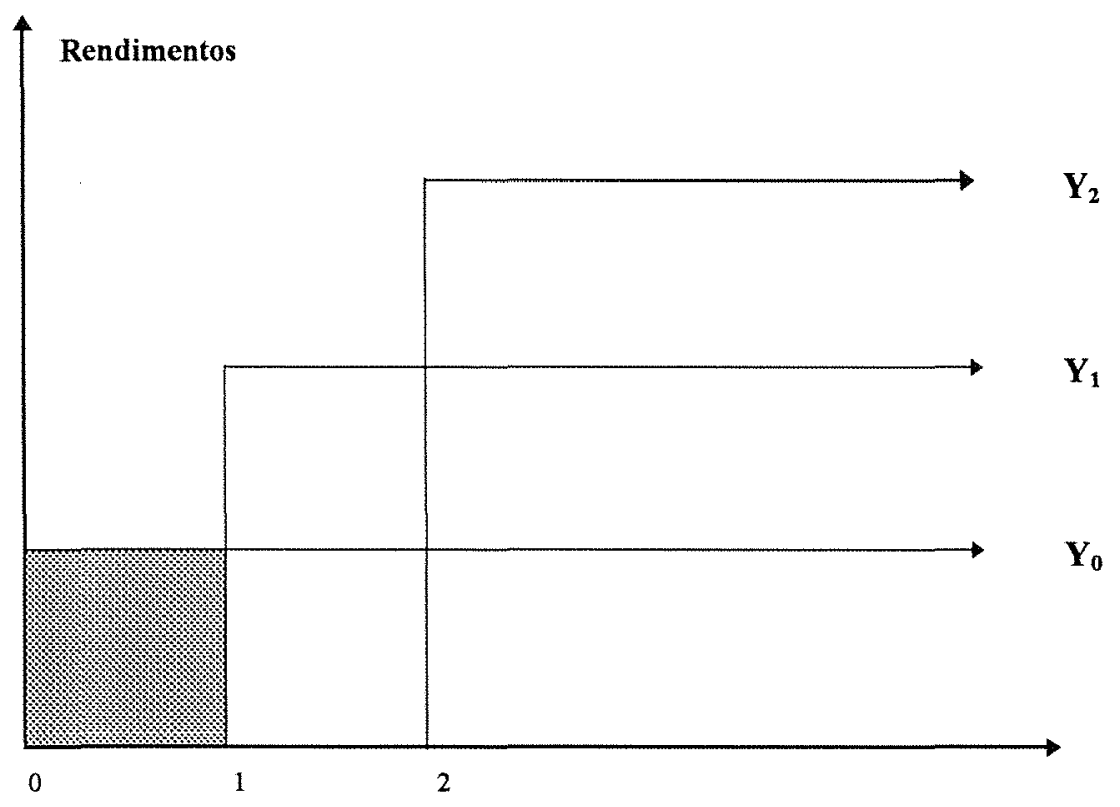

Tempo (anos)

Figura 1. Relação entre rendimentos e tempo de escolaridade.

$\mathrm{O}$ indivíduo ao decidir investir um ano em educação, durante o período de tempo $0-1$, incorrerá num custo representado pela área sombreada. Os beneficios do investimento se refletem na forma de um rendimento mais elevado $Y_{1}$ relativamente ao salário inicial $Y_{0}$ do indivíduo que não possui educação. A taxa de retorno sobre 0 
primeiro ano de escolaridade é então calculada dividindo os beneficios do investimento pelo seu custo decorrente, que é dado por:

$$
r_{1} \equiv\left(Y_{1}-Y_{0}\right) / Y_{0}
$$

onde $Y_{1}$ são os rendimentos após um ano de escolaridade e $Y_{0}$ são os rendimentos sem a escolaridade, onde pressupõe-se que ambos sejam constantes ao longo de toda sua vida. $\mathrm{E}_{1}$ é, por definição, a taxa de retorno do investimento em um ano de educação formal. A equação (1) pode ser rescrita como:

$$
\mathrm{Y}_{1} \equiv \mathrm{Y}_{0}\left(1+\mathrm{r}_{1}\right)
$$

Similarmente para 2 anos de escolaridade, a taxa de retorno $r_{2}$ é definida da seguinte maneira:

$$
\mathrm{r}_{2} \equiv\left(\mathrm{Y}_{2}-\mathrm{Y}_{1}\right) / \mathrm{Y}_{1}
$$

sendo $\mathrm{Y}_{2}$ os rendimentos do $2^{\underline{0}}$ ano adicional de escolaridade, isto indica que

$$
\mathrm{Y}_{2} \equiv \mathrm{Y}_{1}\left(1+\mathrm{r}_{2}\right) \equiv \mathrm{Y}_{0}\left(1+\mathrm{r}_{1}\right)\left(1+\mathrm{r}_{2}\right)
$$

Generalizando para $S$ anos de escolaridade, têm-se:

$$
\mathrm{Y}_{S} \equiv \mathrm{Y}_{0}\left(1+\mathrm{r}_{1}\right)\left(1+\mathrm{r}_{2}\right) \ldots\left(1+\mathrm{r}_{S}\right)
$$

Considerando que a taxa de retorno à escolaridade é igual para todos os níveis de escolaridade, ou seja, $r_{1}=r_{2}=\ldots=r_{S} ;$ e, assumindo que $r_{S}$ é uma taxa média de retorno à cada período adicional de escolaridade (considerando capitalização crescente), obtêm-se: 


$$
\mathrm{Y}_{S}=\mathrm{Y}_{0}\left(1+\mathrm{r}_{S}\right)^{S}
$$

onde $S$ é o número de anos de escolaridade.

Se for aplicado logaritmo nos dois lados da igualdade (6), tem-se:

$$
\ln \mathrm{Y}_{S}=\ln \mathrm{Y}_{0}+S \ln \left(1+\mathrm{r}_{S}\right)
$$

Para valores muito pequenos, $\ln \left(1+r_{S}\right) \cong r_{S}$, e incorporando o termo representativo das perturbações aleatórias, pode-se rescrever a expressão como

$$
\ln Y_{S}=\ln Y_{0}+r_{S} S+u_{i}
$$

A equação (8) é forma básica da equação de rendimentos. É importante lembrar que esta estimativa de taxa de retorno não considera os custos diretos da educação (os únicos custos considerados são os indiretos). A equação (8) também despreza alguns subsídios públicos para a educação (bolsas de estudos), e ainda omite as possíveis externalidades positivas da educação. Se esta equação for estimada por mínimos quadrados utilizando-se dados sobre a escolaridade e o logaritmo dos rendimentos, o coeficiente de inclinação estimado resulta numa taxa de retorno à escolaridade $\left(\mathrm{r}_{\mathrm{s}}\right)$, e o intercepto é o nível de rendimento de um indivíduo com escolaridade igual a zero $\left(\mathrm{Y}_{0}\right)$.

Esta simples especificação da equação de rendimentos (também chamada de função rendimentos) foi proposta por Mincer (1974) para também levar em consideração os efeitos da experiência (investimento pós-escola). Uma possibilidade é aperfeiçoar a equação (8) para obter a forma,

$$
\ln \mathrm{Y}_{S}=\ln \mathrm{Y}_{0}+\beta_{1} S+\beta_{2} \mathrm{X}_{i}+u_{i}
$$


onde $\beta_{1}$ é a taxa de retorno à escolaridade, $\beta_{2}$ é a taxa de retorno à experiência (investimento pós-escola), e $\mathrm{X}_{i}$ corresponde aos anos de experiência do i-ésimo trabalhador no mercado de trabalho.

Deve-se considerar que a representação diagramática que permitiu o desenvolvimento analítico deste modelo simplificado de capital humano foi obtida a partir de algumas hipóteses, não devendo ser considerada, necessariamente, como o formato dos perfis de rendimentos dos indivíduos. Espera-se que os perfis sejam côncavos, pois, os rendimentos inicialmente aumentam devido aos ganhos de produtividade agregados à acumulação de experiência no mercado de trabalho, e posteriormente diminuem, à medida que se aproxima o término da atividade profissional, devido a efeitos causados pela obsolescência e depreciação do estoque de capital humano. Isto levou os pesquisadores ${ }^{13}$ refazerem a equação (9) para obter uma fórmula linear em escolaridade, mas quadrática em experiência. Esta fórmula é:

$$
\ln \mathrm{Y}_{S}=\ln \mathrm{Y}_{0}+\beta_{1} S+\beta_{2} \mathrm{X}_{i}+\beta_{3} \mathrm{X}_{i}^{2}+u_{i}
$$

Como dito anteriormente, a função rendimentos é côncava em relação à variável experiência, então a estimativa de $\beta_{2}$ deve ser positiva, ao passo que a de $\beta_{3}$ deve ser negativa.

\subsection{Algumas omissões de variáveis na equação de rendimentos}

O modelo que se acha configurado na equação (10) supõe que a taxa média de retorno à escolaridade não varia entre indivíduos e que o nível inicial de rendimentos $\left(\mathrm{Y}_{0}\right)$

\footnotetext{
${ }^{13}$ Para detalhes sobre a incorporação da variável experiência e experiência ao quadrado na equação de rendimentos, ver Mincer (1974) e Macedo (1982).
} 
é igual para todos os trabalhadores. Como o modelo básico não contempla as possiveis diferenças de habilidade natural entre os indivíduos, alguns pesquisadores enfatizam que é inapropriado considerar a força de trabalho como homogênea ${ }^{14}$. O procedimento correto seria introduzir uma variável que medisse habilidade no lado direito da equação da função rendimentos, pois argumenta-se que os rendimentos teriam uma relação direta com a habilidade natural, isto é, considerando o mesmo grau de escolaridade, os indivíduos dotados de maiores habilidades conseguiriam maiores rendimentos no mercado de trabalho, ou seja um mesmo investimento com retornos distintos. Esta suposta correlação positiva entre habilidade e escolaridade pode-se originar do fato de quanto maior a habilidade natural maiores são as probabilidades de sucesso na escola; e/ou porque aqueles mais hábeis tenham uma propensão maior a investir em educação (pois possuem uma taxa de retorno esperada mais elevada).

Dado que habilidade e escolaridade são realmente correlacionadas positivamente, surgiriam estimativas tendenciosas no coeficiente da variável escolaridade, ao se estimar os coeficientes da equação dos rendimentos sem a inclusão de uma variável que represente a habilidade natural. Ou seja, a variável escolaridade captaria parte do efeito da variável omitida.

Alguns trabalhos empíricos tentam incorporar algumas medidas de habilidade natural na equação dos rendimentos.

Psacharopoulos \& Velez (1992) trabalharam com dados referentes a trabalhadores colombianos de todos os setores econômicos, que responderam a testes de habilidade e de conhecimentos gerais. Os resultados mostraram que sem a introdução da variável habilidade na equação, a taxa de retorno à escolaridade foi de $10,5 \%$, quando se adiciona habilidade no lado direito da equação, a taxa de retorno cai para 9,4\%; e, finalmente, quando incorpora-se a habilidade e conhecimento geral na regressão, a taxa de retorno fica em $8,5 \%$. Este resultado comprova, segundo os autores, o papel positivo

${ }^{14}$ Ver Griliches (1977). 
da educação sobre os rendimentos dos trabalhadores, mesmo quando se considera as habilidades naturais e conhecimentos gerais ${ }^{15}$.

Uma outra hipótese do modelo é que a taxa de retorno à educação é invariável entre os indivíduos. Isto omite a importância que a qualidade da educação e o papel do ambiente familiar têm sobre os rendimentos dos indivíduos.

A atitude de se investir em educação escolar reincide sobre a família, que assume as decisões de qualificação da criança. Este fato sugere que o ambiente familiar pode ter um impacto sobre a escolaridade dos filhos. Barros \& Lam (1993) e Lam \& Schoeni (1993) avaliam o impacto da educação dos pais e/ou familiares sobre a escolaridade dos filhos no Brasil. Ambos enfatizam que existe uma modesta sensibilidade da educação das crianças em relação à educação dos pais no país.

Sabe-se que a qualidade das instituições de ensino pode variar através do tempo e no espaço geográfico de um país. Se isto realmente ocorre, os indivíduos que freqüentaram as melhores escolas, provavelmente, deveriam ser mais produtivos e, por conseguinte, atingir maiores niveis de rendimento do que as pessoas que freqüentaram escolas de qualidade inferior. $O$ aspecto qualitativo dos efeitos da escolaridade nos rendimentos pode levar a estimativas viesadas, pois a variável anos de escolaridade em muitos casos é uma medida que não reflete a realidade. Poucas pesquisas utilizam alguma proxy ${ }^{16}$ que procure incorporar o efeito da qualidade na equação dos rendimentos, devido à enorme dificuldade em mensurar a qualidade da escolaridade.

\footnotetext{
${ }^{15}$ Os resultados empíricos de acordo com Senna (1976), apontam que os vieses no coeficiente da variável escolaridade situam-se entre 1 e $35 \%$, dependendo da medida de habilidade utilizada e das variáveis que são mantidas inalteradas. Além disso, é muito dificil definir qual medida de habilidade é apropriada para medir a habilidade do individuo para produzir e obter renda no mercado. No nosso estudo, devido a falta de dados, não é possível medir as diferenças de habilidade entre os indivíduos.

${ }_{16}$ Link \& Ratledge (1975) a partir de dados da National Longitudinal Survey para o ano de 1968 , utilizando com proxy a despesa média anual por distrito por estudante, estimaram que o coeficiente da variável escolaridade quase não se modifica (apenas $2 \%$ ) quando se adiciona a variável qualidade da educação (significativo a 1\%) na equação dos rendimentos (Senna, 1976).
} 


\subsection{Procedimento de Heckman}

Além da omissão de variáveis de dificil mensuração na equação de rendimentos, a sua estimativa por mínimos quadrados ordinários (MQO) poderia causar um viés nos coeficientes estimados, devido à seletividade amostral que existe, ao se considerar apenas os indivíduos que participam do mercado de trabalho (ou seja, que possuem rendimentos). Sabe-se que há um grande número de indivíduos que não participam do mercado de trabalho, mas que são essenciais para a obtenção de estimativas consistentes dos parâmetros nas equações dos rendimentos. Heckman $(1980)^{17}$ desenvolveu um procedimento para estimar a equação dos rendimentos evitando o viés da seletividade amostral.

Supondo que $L^{*}$ é uma variável que representa a participação na força de trabalho, então pode-se escrever:

$$
L_{i}^{*}=\gamma^{\prime} Z_{i}+u_{i}
$$

onde $Z_{i}$ é um vetor de variáveis que determinam a participação no mercado de trabalho.

Observe que $L^{*}$ não é observada na prática. Por outro lado, a variável $L$ pode ser operacionalizada do seguinte modo:

$$
\begin{array}{lll}
L_{i}=1 & \text { se } & L_{i}^{*}>0 \\
L_{i}=0 & \text { se } & L_{i}^{*} \leq 0
\end{array}
$$

Representando $W$ como sendo os rendimentos,

\footnotetext{
${ }^{17}$ Ver também Kassouf (1993, 1994 e 1996)
} 


$$
W_{i}=\beta R_{i}+v_{i}
$$

onde $R_{i}$ é um vetor de variáveis que determinam os rendimentos.

A variável $W$ é observada quando $L^{*}$ é maior do que zero. Assumindo que $u_{i}$ e $v_{i}$ têm distribuição normal bivariada com médias zero, desvios padrão $\sigma_{u}$ e $\sigma_{v}$, e correlação $\rho$, então, tem-se, segundo Heckman $(1980)^{18}$, que

$$
\begin{gathered}
\mathrm{E}\left(W_{i} \mid W_{i} \text { é observado }\right)=\mathrm{E}\left(W_{i} \mid L_{i}^{*}>0\right)=\mathrm{E}\left(W_{i} \mid u_{i}>-\gamma^{\prime} Z_{i}\right) \\
=\beta R_{i}+\mathrm{E}\left(v_{i} / u_{i}>-\gamma^{\prime} Z_{i}\right) \\
=\beta R_{i}+\rho \sigma_{u} \lambda_{i}\left(\alpha_{u}\right)
\end{gathered}
$$

onde,

$$
\lambda_{i}\left(\alpha_{u}\right)=\frac{\phi\left(\frac{\gamma \cdot Z_{i}}{\sigma_{u}}\right)}{\Phi\left(\frac{\gamma^{\prime} Z_{i}}{\sigma_{u}}\right)}
$$

e $\phi$ é a função densidade de probabilidade e $\Phi$ é a função de distribuição para uma distribuição normal. A função $\lambda\left(\alpha_{u}\right)$ é denominada inverso da razão de Mill.

A partir da equação (13), a regressão pode ser rescrita como:

$$
W \mid L^{*}>0=\beta^{\prime} R_{i}+\beta_{\lambda} \lambda_{i}\left(\alpha_{u}\right)+\varepsilon_{i}
$$

\footnotetext{
${ }^{18}$ Para maiores detalhes matemáticos, ver Heckman (1980). Esta metodologia ficou conhecida na literatura como procedimento de Heckman.
} 
Observando a equação (14), percebe-se que, ao ajustar a equação dos rendimentos em função de $R$ utilizando a técnica de mínimos quadrados ordinários, e fazendo uso apenas de informações para os individuos que estão participando do mercado de trabalho, as estimativas de $\beta$ seriam inconsistentes, pois, está-se omitindo a variável $\lambda\left(\alpha_{u}\right)$.

Entretanto, utilizando os mínimos quadrados ordinários para estimar a regressão dos rendimentos em função de $R$ e $\lambda$ [isto é, ajustando a equação (14)], a partir de dados em que se considera somente os indivíduos que estão participando do mercado de trabalho, resultaria em estimadores consistentes de $\beta$ (corrigindo o viés de seletividade).

Com base neste fato, Heckman propôs o seguinte procedimento: inicialmente, efetuar a regressão de $L$ em função de $Z$ pelo método da máxima verossimilhança utilizando um modelo próbite [ou seja, ajustar a equação (11)], onde $L$ assumirá o valor 0 se o indivíduo não está inserido no mercado de trabalho e 1 se o indivíduo é participante do mercado de trabalho (equação de participação no mercado de trabalho). Com as estimativas de $\gamma$ resultantes deste modelo é possível calcular as estimativas de $\lambda$. Obtendo-se as estimativas de $\lambda$, pode-se efetuar a regressão de $W$ em função de $R$ e $\hat{\lambda}$ [usando a equação (14)], utilizando mínimos quadrados ordinários (equação de rendimentos), e conseguir estimadores consistentes de $\beta$. 


\section{DADOS A SEREM UTILIZADOS}

A base de dados utilizada no presente trabalho foi a Pesquisa Nacional por Amostra de Domicílios (PNAD), relativa ao ano de 1995. A coleta desses dados foi realizada pela Fundação Instituto Brasileiro de Geografia e Estatística (IBGE) e realizada no período de 24 a 30 de setembro de 1995. Entrevistaram-se aproximadamente 334.000 pessoas de dez anos ou mais em 102.787 domicílios.

Partindo do total de informações disponíveis para estudo, selecionaram-se aquelas informações cujos entrevistados possuem entre 21 e 59 anos, que residem no setor urbano, obtendo, com isto, uma amostra mais homogênea da força de trabalho, tentando englobar um número significativo de pessoas participantes do mercado de trabalho. Isto porque a participação no mercado de trabalho de pessoas muito jovens é reduzida $^{19}$, e, pessoas mais idosas não estão mais inseridas no mercado de trabalho (grande parte se aposenta). O número de indivíduos resultante foi 165.139 .

Está bem estabelecido na literatura (como visto no capítulo 3) que não somente "escolaridade e experiência" explicam as diferenças entre os rendimentos dos indivíduos, mas que existe um conjunto de variáveis, inerentes ao mercado e às pessoas, que devem ser consideradas para auxiliar na explicação do comportamento e dispersão dos ganhos.

\footnotetext{
${ }^{19}$ De acordo o Instituto Nacional de Estudos e Pesquisas Educacionais do Ministério da Educação e Desporto (Inep/MEC), o tempo médio de conclusão do ensino fundamental ( $1^{\underline{a}}$ a $8^{\underline{a}}$ série) no Brasil é de 11 anos e 2 meses.
} 
A seguir, descreve-se quais variáveis podem ser obtidas a partir da PNAD e que podem, segundo a literatura disponivel, ter influência sobre os rendimentos. Para cada variável comenta-se os arranjos que foram efetuados para alcançar o objetivo proposto na presente dissertação. As variáveis consideradas são: rendimentos, anos de estudo (escolaridade), experiência, ramo de atividade, filiação a sindicatos, setor de emprego, região e raça. As últimas cinco variáveis permitem verificar aspectos de segmentação no mercado de trabalho ${ }^{20}$.

\subsection{Descrição das variáveis}

\section{$\underline{\text { Rendimentos }}$}

Os dados da PNAD fornecem informações sobre o rendimento mensal (em reais) do trabalho principal recebido pelos individuos que participavam do mercado de trabalho na semana anterior à entrevista. O número fornecido de horas trabalhadas por semana foi multiplicado por quatro para se calcular o montante de horas trabalhadas por mês no trabalho principal. O valor da taxa do rendimento mensal foi, então, dividido pelo número de horas trabalhadas por mês, a fim de se obter a taxa de rendimento por hora.

\section{Anos de estudo}

A PNAD traz informações da série e do grau escolar que a pessoa estava freqüentando ou havia freqüentado, considerando a última série concluída com

\footnotetext{
${ }^{20}$ A existência de diferenciação nos rendimentos entre trabalhadores pode ser explicada pela segmentação do mercado de trabalho. De acordo com o relatório sobre o desenvolvimento humano no Brasil (1996), duas são as razões mais comumente apontadas para a segmentação: (i) aspectos institucionais, aí incluída a ação dos sindicatos, e (ii) os efeitos das empresas que englobam fatores diversos como tecnologia, tamanho, origem do capital, ramo de atividade, etc.
} 
aprovação. A correspondência entre anos de estudo e série por grau escolar foi feita de forma que cada série concluída com aprovação correspondeu a 1 ano de estudo. A contagem dos anos de estudo teve início em 1 ano, a partir da primeira série concluída com aprovação de curso de primeiro grau ou elementar.

\section{Experiência}

É sempre problemática, para a estimação da equação dos rendimentos, a identificação da experiência e/ou treinamento no mercado de trabalho. Raramente existem dados diretos sobre os anos de experiência do trabalhador, tornando-se necessário utilizar uma proxy ${ }^{21}$ nas estimações. Utilizar-se-á, nesse trabalho, uma medida de experiência igual a idade atual (anos) menos a idade com que o individuo começou a trabalhar (ex.: uma pessoa que está com 40 anos de idade, e começou a trabalhar com 20 anos de idade possui, então, 20 anos de experiência no mercado de trabalho).

Alguns autores ${ }^{22}$ afirmam que há uma séria dúvida sobre a experiência profissional poder refletir em aumento real do capital humano. Sabe-se que, no Brasil, existem muitas crianças que deixam de ir à escola para ajudar no orçamento familiar, trabalhando em subempregos ou em atividades que não podem ser consideradas como acréscimo em capital humano. O presente trabalho considera a idade de 10 anos como sendo a idade mínima para aquisição de experiência, isto é, para ingresso no mercado de trabalho.

\footnotetext{
${ }^{21}$ A maioria dos estudos baseia-se na idéia de que um indivíduo inicia sua educação aos sete anos de idade e entra no mercado de trabalho assim que termina seus estudos. No Brasil, onde o índice de repetência escolar é significativo (segundo o IBGE) e nem todos os indivíduos começam sua vida escolar com a mesma idade, também existem casos em que as pessoas começam a trabalhar antes de se formarem e a hipótese de terem estado continuamente empregado aplica-se a uma parte da força de trabalho, portanto, a aplicação dessa proxy pode ser problemática.

${ }^{22}$ Lam \& Levison (1990) fizeram uma discussão sobre a partir de que idade a experiência efetiva no mercado de trabalho pode ser considerada.
} 
$\underline{\text { Ramo de atividade }}$

Para Branco (1979), citado por Barros \& Mendonça (1995), os ramos de atividade que crescem mais rapidamente tendem a pagar salários mais elevados. Por outro lado, se determinados indivíduos trabalham em um setor que apresenta maior grau de concentração, é provável que seu rendimento seja comparativamente maior do que o de outros indivíduos com a mesma qualificação, mas que trabalham em empresas de setores mais competitivos.

Barros \& Reis (1995) concluíram que, se a desigualdade salarial gerada pela segmentação por ramo de atividade fosse totalmente eliminada, ceteris paribus, seria reduzido em $15 \%$ o diferencial nos rendimentos, o que representa um valor significativo.

A variável ramo de atividade na PNAD pode ser definida a partir das informações relativas ao ramo de atividade do trabalho principal $^{23}$ : empregado no setor primário, empregado no setor secundário, empregado no setor terciário.

À medida em que os países se desenvolvem, a maioria dos trabalhadores desloca-se para empregos de maior produtividade e melhores salários na indústria e nos serviços [Relatório sobre o Desenvolvimento Mundial (1995)]. Então, espera-se os indivíduos que trabalham nos setores terciário e secundário auferem maiores rendimentos que os do setor primário. Para captar o efeito das diferenças nos rendimentos, será omitida a variável empregado no setor primário e serão analisados os efeitos das outras variáveis nos rendimentos em relação à omitida (variáveis binárias que assume valor 1 se $o$ indivíduo trabalhar no setor secundário e/ou se trabalhar no setor terciário).

${ }^{23}$ As agregações em seus respectivos setores, encontram-se descritas nos anexos. 


\section{Filiação a sindicatos ${ }^{24}$}

Em um sistema eficaz de relações de trabalho, que procura o ponto de equilibrio entre as necessidades das empresas de permanecerem competitivas e as aspirações dos trabalhadores a rendimentos maiores e melhora das condições de trabalho, o papel do sindicato é fundamental. Os sindicatos agem como representantes dos trabalhadores, organizando grande número deles numa entidade única com o poder equiparado ao do empregador. Assume-se que a filiação ao sindicato por parte do trabalhador tem efeito positivo sobre a renda do produtor, devido ao aumento no seu poder de barganha. A filiação ao sindicato é uma variável binária que assume valor igual a 1 se o trabalhador é sindicalizado e zero, caso contrário.

\section{$\underline{\text { Setor de emprego }}$}

O setor de emprego em que o trabalhador está inserido é uma variável binária de valor igual a 1 se o trabalhador é do setor privado. Incluiu-se esta variável para verificar possíveis diferenças de rendimentos entre setor privado e público (administração direta e indireta municipal, estadual e federal).

\section{$\underline{\text { Região }}$}

O Brasil apresenta disparidades regionais em seus dotes de recursos humanos e fisicos, taxas de crescimento e renda que podem refletir nos tipos de indústria e nas atividades econômicas de cada região e, consequentemente, no mercado de trabalho. Os custos relativos dos fatores de produção podem variar entre regiões e tal fato tem influência nos niveis de rendimento.

\footnotetext{
${ }^{24}$ Segundo a PNAD, entendeu-se como sindicato a associação de uma ou mais categorias para fins de estudo, defesa e coordenação de interesses econômicos e profissionais de todos aqueles que exercessem atividades ou profissões idênticas, similares ou conexas, e que tivesse Carta de Reconhecimento do Ministério do Trabalho ou registro em cartório como tal. Não se considerou como associada a sindicato a pessoa que representava uma empresa filiada a sindicato patronal.
} 
As regiões do Brasil serão representadas por variáveis binárias: Norte; Sul; Sudeste; Centro-Oeste; Nordeste. Existem diferenças significativas entre essas regiões, que refletem em desigualdade nos rendimentos. Para confirmar esta hipótese, nas regressões a variável Nordeste será omitida, pois considera-se que essa região que apresenta os maiores índices de pobreza no Brasil [Relatório sobre desenvolvimento humano (1996)].

$\underline{\text { Raça }}$

Alguns indivíduos apresentam status relativamente baixo no mercado de trabalho. Em muitos casos, isto está associado à etnia das pessoas. Isto faz com que trabalhadores idênticos, do ponto de vista da produtividade, recebam remunerações diferentes dependendo de sua cor.

Esse diferencial de renda decorre, em parte, das características raciais associadas a determinados contingentes populacionais. De acordo com o índice sobre desenvolvimento humano no Brasil (1996) "ao considerar a dimensão regional, verificase que a composição racial da população varia de acordo com as regiões fisiográficas": no Sul e Sudeste, predominam as pessoas de cor branca $(84,3 \%$ e $65,7 \%$, respectivamente); nas regiões Norte e Nordeste, as de cor parda e/ou negra (70,7 \% e $71,9 \%$ respectivamente), conforme a PNAD de 1995. Existe uma correlação entre regiões com maiores rendimentos e composição racial. Isto denota que as pessoas de cor negra estão concentradas, principalmente, naquelas regiões em que é mais baixo o nível de renda per capita, o que pode explicar parte do diferencial observado. Do mesmo modo, as pessoas de cor negra ou parda possuem menor nível de escolaridade que o das pessoas de cor branca. Quando se comparam pessoas de diferentes cores em uma mesma região, e com o mesmo nível educacional, constata-se que o diferencial entre negros e brancos, embora menor, é ainda significativo (Tabela 1) 
Tabela 1. Diferencial de renda entre as populações negra, parda e a branca - 1990 (Renda média dos brancos $=100$ ).

\begin{tabular}{lcccc}
\hline & \multicolumn{2}{c}{ Homens } & \multicolumn{2}{c}{ Mulheres } \\
\cline { 2 - 5 } & Negros & Pardos & Negros & Pardos \\
\hline Diferencial bruto & 63 & 68 & 68 & 68 \\
Diferencial & 74 & 79 & 86 & 82 \\
liquido* & & & & \\
\hline
\end{tabular}

Fonte: Barros, Mendonça e Velasco, 1996 . In: Relatório sobre o desenvolvimento humano no Brasil, 1996.

*Corrigido para as diferenças regionais e de nível educacional.

Para verificar esta diferença nos rendimentos entre os indivíduos de diferentes raças, variáveis binárias são utilizadas para captar os efeitos da discriminação racial, divididas em: indivíduos brancos e amarelos (a raça amarela representa menos de $1 \%$ da população); pardos e negros. A variável indivíduos de raça negra (por apresentarem menores rendimentos) será omitida.

\subsection{Modelos a serem estimados}

O procedimento de Heckman foi empregado para estimar a equação dos rendimentos. Primeiramente, uma equação próbite [equação (11)] é estimada, em que a variável dependente assume valor um se o indivíduo obtém renda positiva do seu trabalho e zero, caso contrário.

As variáveis que influenciam a decisão sobre a participação no mercado de trabalho são: educação ou anos de escolaridade (EDUCAÇÃO), experiência em anos 
(EXPER), experiência ao quadrado $\left(\right.$ EXPER $\left.^{2}\right)$, interação entre anos de escolaridade e anos de experiência (EXPER x EDUC), região onde reside (SUDESTE, CENTROOESTE, SUL, SUDESTE e NORDESTE, esta última é omitida), cor ou raça [PARDA, BRAMA (branca ou amarela) e NEGRA, que é omitida], condição na familia [CHEFE, FILHO(A) e OUTROS ${ }^{25}$, esta última é omitida], renda não-salarial em reais (RNSAL, que inclui: alugueis, pensão, dividendos de aplicações financeiras etc.), número de filhos(as) de 0 a 2 anos de idade [FILHO(A)0-2], de 3 a 5 anos [FILHO(A)3-5], de 6 a 12 anos [FILHO(A)6-12], filhos adolescentes de 13 anos ou mais (FILHO $\geq 13$ ) e filhas de 13 anos ou mais (FILHA $\geq 13$ ).

Todas as variáveis que afetam os homens sobre a decisão da participação no mercado de trabalho são também utilizadas para as mulheres, incluindo ainda para as mulheres a variável CÔNJUGE (condição no domicílio), pois, espera-se que os chefes trabalhem mais do que as cônjuges. Foram também incluídas as variáveis escolaridade do marido em anos (EDU-MAR) e experiência do marido em anos (EXP-MAR), por considerar que o nivel de renda do marido influencia a decisão da mulher no ingresso no mercado de trabalho. Como o rendimento do marido é uma variável endógena, utilizamse essas duas variáveis por estarem intimamente ligadas aos rendimentos do marido, isto é, quanto maior sua escolaridade e experiência, maiores são as oportunidades de trabalho e melhores são os rendimentos do marido, diminuindo a necessidade de a mulher trabalhar.

Utiliza-se variáveis binárias para a posição do indivíduo na familia, pois esperase que a probabilidade de maior participação no mercado de trabalho, por assumir maior responsabilidade na geração da renda familiar.

${ }^{25}$ Inclui outros parentes, agregado, pensionista, empregado doméstico e parente empregado doméstico. 
Construiu-se variáveis binárias para as regiões do Brasil, com intuito de verificar se as disparidades regionais existentes no pais, podem refletir nas oportunidades de trabalho.

As variáveis binárias para os grupos de raça, foram incluídas para tentar captar alguma diferença na probabilidade de inserção no mercado de trabalho entre as raças.

Com base nos coeficientes das equações de participação no mercado de trabalho [equação (11)] calculam-se as variáveis $l a m b d a^{26}$. Os valores estimados de lambda são utilizadas nas equações de rendimentos [equação (14)].

Devido à informações incompletas a respeito de algumas variáveis (sendo excluída a observação que não apresentava as informações de todas as variáveis utilizadas no trabalho), a amostra resultante foi de 73.033 mulheres e 64.870 homens. No período da entrevista da PNAD-1995, 85,02\% dos homens e 50,98\% das mulheres possuíam rendimentos provenientes do trabalho. As Tabelas 2 e 3 fornecem a descrição das variáveis a serem utilizadas neste trabalho, assim como as médias e os desvios padrão de toda a amostra (participantes e não-participantes do mercado de trabalho) e dos indivíduos que estão inseridos no mercado de trabalho, que serão utilizadas na equação de participação do trabalho e dos rendimentos, respectivamente.

Com relação aos indivíduos que estão engajados no mercado de trabalho, observa-se que a média dos anos de escolaridade das mulheres é maior que a dos homens ( 7,55 e 6,59 , respectivamente), enquanto o rendimento médio ${ }^{27}$ dos homens supera o das mulheres em $39,2 \%$. Por outro lado, os homens possuem maior tempo de experiência no mercado de trabalho que as mulheres. Este fato decorre, em grande parte, do maior

\footnotetext{
${ }^{26}$ Inverso da razão de Mill.

${ }^{27} \mathrm{O}$ rendimento por hora médio de homens e mulheres analfabetos que estão inseridos no mercado de trabalho são $\mathrm{R} \$ 1,06$ e $\mathrm{R} \$ 0,34$ reais, respectivamente.
} 
tempo que as mulheres permanecem na escola, adiando sua inserção no mercado de trabalho.

Além deste fato, o ciclo de vida ativa das mulheres é mais irregular que os dos homens, por ser afetado pelo ciclo vital do casamento, fecundidade e família. Este último faz o tempo da mulher ser alocado em três maneiras, segundo Ramos \& Soares (1995): i) realização de atividades domésticas, incluindo a educação dos filhos; ii) desempenho de atividades no mercado de trabalho; e, iii) lazer (qualquer atividade que não faz parte dos dois conjuntos anteriores). 
Tabela 2. Descrição das variáveis, médias e desvios padrão, para homens e mulheres participantes e não-participantes do mercado de trabalho.

\begin{tabular}{|c|c|c|c|}
\hline Variável & Definição & Média & D. P. \\
\hline \multicolumn{4}{|l|}{ Homens } \\
\hline $\begin{array}{l}\text { EDUCAÇÃO } \\
\text { EXPER } \\
\text { EXPER } \\
\text { EXPER X EDUC } \\
\text { CHEFE } \\
\text { FILHO } \\
\text { SUDESTE } \\
\text { SUL } \\
\text { CENTRO-OESTE } \\
\text { NORTE } \\
\text { FILHO (A) } 0-2 \\
\text { FILHO (A) } 3-5 \\
\text { FILHO (A) } 6-12 \\
\text { FILHO } 213 \\
\text { FILHA } 213 \\
\text { RNSAL } \\
\text { BRAMA } \\
\text { PARDO }\end{array}$ & $\begin{array}{l}\text { anos de escolaridade } \\
\text { anos de experiência } \\
\text { anos de experiência ao quadrado } \\
\text { experiência x educação } \\
=1 \text { se o individuo é chefe da familia } \\
=1 \text { se o individuo é filho } \\
=1 \text { se o individuo reside na região Sudeste } \\
=1 \text { se o individuo reside na região Sul } \\
=1 \text { se o indivíduo reside na regiäo Centro-Oeste } \\
=1 \text { se o individuo reside na região Norte } \\
\text { número de filhos(as) de } 0 \text { a } 2 \text { anos de idade } \\
\text { número de filhos(as) de } 3 \text { a5 anos de idade } \\
\text { número de filhos(as) de } 6 \text { a } 12 \text { anos de idade } \\
\text { número de filhos adolescentes de } 13 \text { anos ou mais } \\
\text { número de filhas adolescentes de } 13 \text { anos ou mais } \\
\text { renda não-salarial } \\
=1 \text { se o indivíduo é branco ou amarelo } \\
=1 \text { se o individuo é pardo }\end{array}$ & $\begin{array}{r}6,46 \\
22,84 \\
663,8 \\
134,2 \\
0,74 \\
0,21 \\
0,51 \\
0,15 \\
0,07 \\
0,05 \\
0,20 \\
0,21 \\
0,54 \\
0,18 \\
0,29 \\
48,73 \\
0,58 \\
0,35\end{array}$ & $\begin{array}{r}4,31 \\
11,88 \\
608,41 \\
119,09 \\
0,43 \\
0,41 \\
0,48 \\
0,38 \\
0,31 \\
0,27 \\
0,496 \\
0,49 \\
0,93 \\
0,61 \\
0,69 \\
315,79 \\
0,49 \\
0,48\end{array}$ \\
\hline \multicolumn{4}{|l|}{ Mulheres } \\
\hline $\begin{array}{l}\text { EDUCAÇÃO } \\
\text { EXPER } \\
\text { EXPER } \\
\text { EXPER } \times \text { EDUC. } \\
\text { CHEFE } \\
\text { CÔNJUGE } \\
\text { FILHO } \\
\text { SUDESTE } \\
\text { SUL } \\
\text { CENTRO-OESTE } \\
\text { NORTE } \\
\text { FILHO (A) } 0-2 \\
\text { FILHO (A) } 3-5 \\
\text { FILHO (A) 6-12 } \\
\text { FILHO } \geq 13 \\
\text { FILHA } \geq 13 \\
\text { EDU-MAR } \\
\text { EXP-MAR } \\
\text { RNSAL } \\
\text { BRAMA } \\
\text { PARDO }\end{array}$ & $\begin{array}{l}\text { anos de escolaridade } \\
\text { anos de experiência } \\
\text { anos de experiência ao quadrado } \\
\text { experiência x educação } \\
=1 \text { se o indivíduo é chefe da família } \\
=1 \text { se o individuo é cônjuge } \\
=1 \text { se o individuo é filho } \\
=1 \text { se o indivíduo reside na região Sudeste } \\
=1 \text { se o indivíduo reside na região Sul } \\
=1 \text { se o individuo reside na região Centro-Oeste } \\
=1 \text { se o indivíduo reside na região Norte } \\
\text { número de filhos(as) de } 0 \text { a } 2 \text { anos de idade } \\
\text { número de filhos(as) de } 3 \text { a } 5 \text { anos de idade } \\
\text { número de filhos(as) de } 6 \text { a } 12 \text { anos de idade } \\
\text { número de filhos adolescentes de } 13 \text { anos ou mais } \\
\text { número de filhas adolescentes de } 13 \text { anos ou mais } \\
\text { educação do marido em anos } \\
\text { experiência do marido em anos } \\
\text { renda não-salarial } \\
=1 \text { se o indivíduo é branco ou amarelo } \\
=1 \text { se o indivíduo é pardo }\end{array}$ & $\begin{array}{r}6,53 \\
23,12 \\
687,2 \\
131,5 \\
0,18 \\
0,63 \\
0,13 \\
0,51 \\
0,15 \\
0,07 \\
0,05 \\
0,20 \\
0,22 \\
0,58 \\
0,22 \\
0,36 \\
5,41 \\
18,4 \\
35,76 \\
0,60 \\
0,34\end{array}$ & $\begin{array}{r}4,38 \\
2,35 \\
638,43 \\
114,84 \\
0,39 \\
0,48 \\
0,34 \\
0,48 \\
0,37 \\
0,31 \\
0,26 \\
0,48 \\
0,49 \\
0,94 \\
0,67 \\
0,74 \\
6,28 \\
18,23 \\
197,75 \\
0,49 \\
0,486\end{array}$ \\
\hline
\end{tabular}

Fonte: Dados da PNAD-1995. 
Tabela 3. Descrição das variáveis, médias e desvios padrão, para homens e mulheres que participam do mercado de trabalho.

\begin{tabular}{|c|c|c|c|}
\hline Variável & Definição & Média & D. P. \\
\hline \multicolumn{4}{|l|}{ Homens } \\
\hline RENDIMENTOS & rendimentos dos individuos em reais/hora & 3,48 & 6,55 \\
\hline $\begin{array}{l}\text { LWAGE } \\
\text { EDUCACÃO }\end{array}$ & $\begin{array}{l}\text { logaritmo da variável rendimentos } \\
\text { anos de escolaridade }\end{array}$ & $\begin{array}{l}0,71 \\
6,59\end{array}$ & $\begin{array}{l}0,97 \\
4,31\end{array}$ \\
\hline EXPER & anos de experiência & 22,46 & 11,34 \\
\hline EXPER $^{2}$ & anos de experiência ao quadrado & 634,1 & 565,44 \\
\hline EXPER X EDUC & experiência $x$ educação & 135,3 & 116,48 \\
\hline SUDESTE & $=1$ se 0 indivíduo reside na região Sudeste & 0,51 & 0,26 \\
\hline SUL & $=1$ se o individuo reside na região Sul & 0,15 & 0,48 \\
\hline CENTRO-OESTE & $=1$ se $o$ individuo reside na região Centro-Oeste & 0,07 & 0,31 \\
\hline NORTE & $=1$ se 0 individuo reside na região Norte & 0,05 & 0,26 \\
\hline SECUNDÁRIO & $=1$ se o indivíduo reside na região Norte & 0,33 & 0,46 \\
\hline TERCIÁRIO & $=1$ se $o$ indivíduo reside na região Norte & 0,58 & 0,48 \\
\hline SINDICALIZADO & $=1$ se o individuo é filiado a algum sindicato & 0,21 & 0,41 \\
\hline PRIVADO & $=1$ se $o$ indivíduo trabalha no setor privado & 0,49 & 0,49 \\
\hline BRAMA & $=1 \mathrm{se} o$ indivíduo é branco ou amarelo & 0,59 & 0,59 \\
\hline PARDO & $=1$ se o indivíduo é pardo & 0,35 & 0,48 \\
\hline LAMBDA & inverso da razão de Mill & 0,23 & $-18,66$ \\
\hline \multicolumn{4}{|l|}{ Mulheres } \\
\hline RENDIMENTOS & rendimentos dos individuos em reais/hora & 2,50 & 4,10 \\
\hline LWAGE & logaritmo da variável rendimentos & 0,41 & 0,95 \\
\hline EDUCAÇÃO & anos de escolaridade & 7,55 & 4,50 \\
\hline EXPER & anos de experiência & 19,90 & 11,31 \\
\hline EXPER $^{2}$ & anos de experiência ao quadrado & 524,8 & 517,12 \\
\hline EXPER $\times$ EDUC. & experiência $x$ educação & 132,6 & 110,46 \\
\hline SUDESTE & $=1$ se o individuo reside na regiāo Sudeste & 0,51 & 0,48 \\
\hline SUL & $=1$ se 0 individuo reside na região Sul & 0,16 & 0,16 \\
\hline CENTRO-OESTE & $=1$ se o individuo reside na região Centro-Oeste & 0,07 & 0,31 \\
\hline NORTE & $=1$ se o indivíduo reside na região Norte & 0,04 & 0,26 \\
\hline SECUNDÁRIO & $=1$ se o indivíduo reside na região Norte & 0,11 & 0,31 \\
\hline TERCIÁRIO & $=1$ se 0 individuo reside na região Norte & 0,87 & 0,32 \\
\hline SINDICALIZADO & $=1$ se o indivíduo é filiado a algum sindicato & 0,17 & 0,37 \\
\hline PRIVADO & $=1$ se o individuo trabalha no setor privado & 0,34 & 0,47 \\
\hline BRAMA & $=1$ se o indivíduo é branco ou amarelo & 0,61 & 0,49 \\
\hline PARDO & $=1$ se o indivíduo é pardo & 0,33 & 0,48 \\
\hline LAMBDA & inverso da razão de Mill & 1,15 & 0,53 \\
\hline
\end{tabular}

Fonte: Dados da PNAD-1995. 


\section{RESULTADOS DAS ESTIMATIVAS DO MODELO ECONOMÉTRICO}

Inicialmente, as equações de participação no mercado de trabalho e dos rendimentos são calculadas separadamente para homens e mulheres. Optou-se pela estimação em dois grupos distintos devido às diferenças entre os rendimentos dos homens e das mulheres. Posteriormente, de forma análoga, são estimadas as equações para cada uma das regiões do país, para trabalhadores filiados e não-filiados a sindicatos, e para trabalhadores do setor público e privado.

\subsection{Participação no Mercado de Trabalho - Homens}

Os resultados do modelo próbite estimados pelo método de máxima verossimilhança [equação (11)] são mostrados na Tabela 4. O teste de razão de verossimilhança que testa se todos os coeficientes das variáveis com valor zero é altamente significativo e igual a $7226,634^{28}$.

Com base nos coeficientes das equações de participação no mercado de trabalho, calcula-se o inverso da razão de Mill, a qual é usada como variável exógena na equação dos rendimentos.

\footnotetext{
${ }^{28}$ Este teste tem distribuição de qui-quadrado com 18 graus de liberdade.
} 
As variáveis educação e a experiência apresentam sinais positivos, indicando que quanto mais escolaridade e experiência maior a probabilidade do indivíduo participar do mercado de trabalho. O sinal negativo da variável experiência ao quadrado aponta uma depreciação do capital humano, isto é, a probabilidade de participação no mercado de trabalho decresce a partir de determinada idade.

Tabela 4. Resultados da equação próbite de participação no mercado de trabalho Homens.

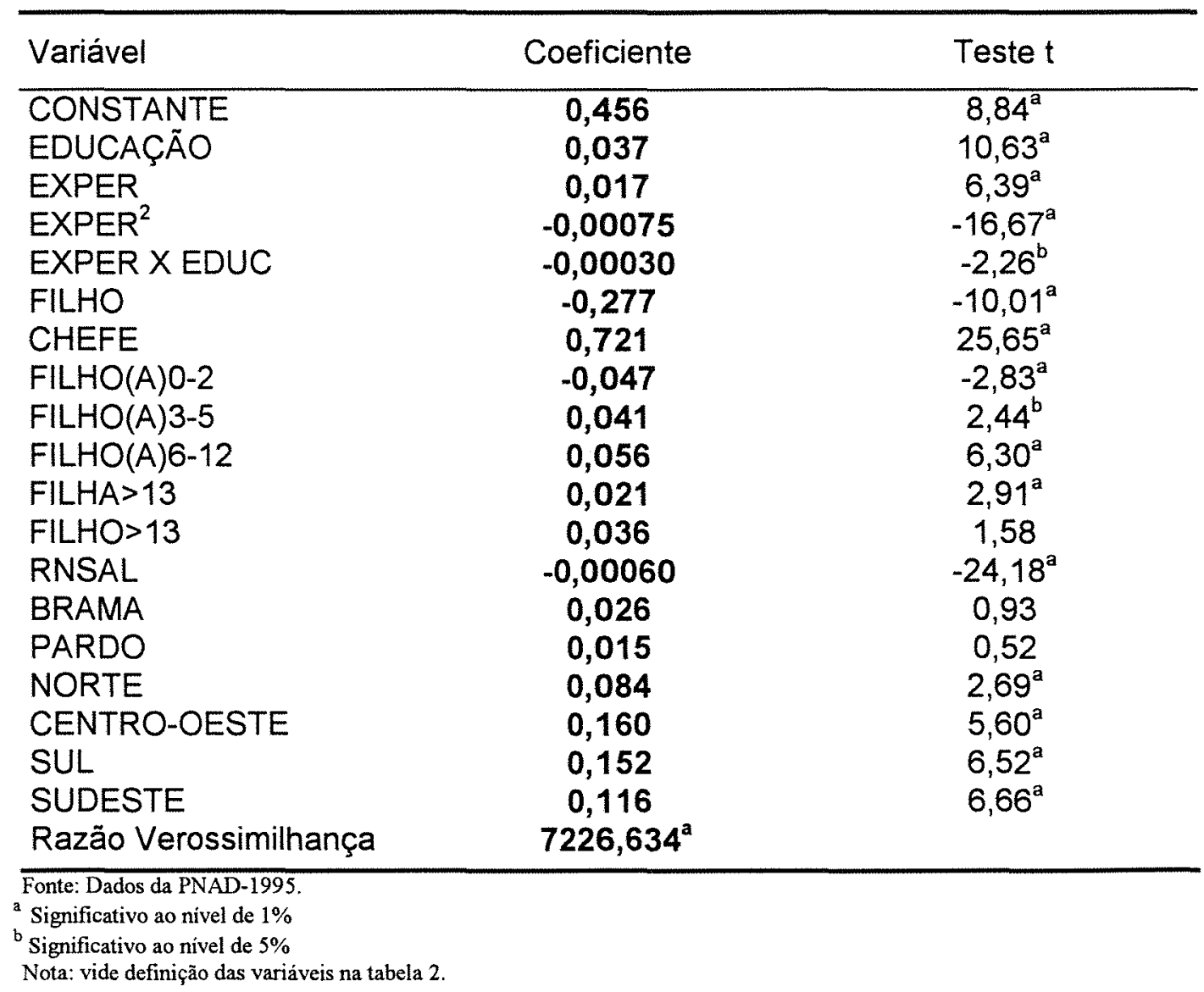

A variável renda não-salarial (RNSAL) é incluída na equação estimada como proxy para riqueza (Tiefenthaler, 1989). Como esperado, quanto maior a riqueza do indivíduo, menor sua probabilidade de participar do mercado de trabalho. 
As variáveis binárias para regiões foram incluidas para captar alguma diferença entre oportunidades que o mercado de trabalho pode oferecer à população. Os resultados mostram que os indivíduos que residem na região Norte, Centro-Oeste, Sul e Sudeste têm mais chances de participar do mercado de trabalho em relação aos habitantes do Nordeste (variável omitida na regressão).

Com relação à posição na familia (CHEFE e FILHO), verifica-se que os chefes participam mais do mercado de trabalho que os filhos, por assumirem importância fundamental na geração do orçamento familiar, de forma a prover o sustento de seus membros.

Em estudo sobre os determinantes da participação no mercado de trabalho, Kassouf (1997) constatou que a probabilidade de inserção no mercado de trabalho dos chefes é maior que a participação dos filhos.

Quanto ao número de filhos, quase todos os coeficientes foram significativos, e apresentaram sinais positivos, mostrando que a participação no mercado de trabalho cresce com o aumento do número de filhos, como conseqüência da maior exigência de renda. A variável FILHO(A)0-2, entretanto, apresenta o coeficiente com valor negativo, indicando que devido aos maiores cuidados maternos exigidos quanto aos filhos pequenos, o homem pode auxiliar em algumas tarefas, que anteriormente eram executadas pelas mulheres, podendo ocasionar uma redução do seu tempo disponível para o trabalho.

\subsection{Equação de Rendimentos - Homens}

Os resultados da equação dos rendimentos [equação (14)] estimada por mínimos quadrados generalizados, ponderando-se pelo fator de expansão da amostra (o IBGE 
utiliza para gerar uma amostra representativa da população brasileira), considerando 55.152 homens que participam do mercado de trabalho, utilizando como variável dependente o logaritmo do rendimento por hora trabalhada, são apresentados na Tabela 5 .

Tabela 5. Resultados da equação dos rendimentos - Homens.

\begin{tabular}{|c|c|c|}
\hline Variável & Coeficiente & Teste $t$ \\
\hline CONSTANTE & $-1,111$ & $3,61^{\mathrm{a}}$ \\
\hline EDUCAÇÃO & 0,096 & $49,96^{a}$ \\
\hline EXPER & 0,024 & $13,75^{\mathrm{a}}$ \\
\hline EXPER $^{2}$ & $-0,00025$ & $-8,34^{a}$ \\
\hline EXPER X EDUC & 0,00082 & $16,26^{a}$ \\
\hline SUDESTE & 0,370 & $32,00^{a}$ \\
\hline SUL & 0,232 & $13,54^{\mathrm{a}}$ \\
\hline CENTRO-OESTE & 0,232 & $12,42^{\mathrm{a}}$ \\
\hline NORTE & 0,188 & $8,39^{a}$ \\
\hline SINDIC & 0,258 & $33,08^{a}$ \\
\hline PRIVADO & $-0,232$ & $-35,84^{a}$ \\
\hline SECUNDA & 0,546 & $29,71^{\mathrm{a}}$ \\
\hline TERCIA & 0,442 & $23,73^{a}$ \\
\hline BRAMA & 0,244 & $16,14^{\mathrm{a}}$ \\
\hline PARDO & 0,059 & $3,65^{\mathrm{a}}$ \\
\hline LAMBDA & $-0,409$ & $-13,65^{a}$ \\
\hline $\mathrm{R}^{2}$ & 0,45 & \\
\hline Teste - F & $3066,12^{\mathrm{a}}$ & \\
\hline
\end{tabular}

Todos os coeficientes estimados são altamente significativos. A variável EDUCAÇÃO mostra que cada ano a mais de escolaridade aumenta os rendimentos dos trabalhadores. Valor bem mais elevado foi encontrado por Leal \& Werlang (1991), aproximadamente 0,16, para homens de 25 a 50 anos no Brasil. Kassouf (1993 e 1994), utilizando o procedimento de Heckman para corrigir o viés da seletividade amostral, 
encontrou valores entre 0,7 e 0,8 para o coeficiente anos de escolaridade para trabalhadores do setor urbano.

Como proposto pela teoria do capital humano, anos adicionais decorrentes da acumulação de educação e experiência no mercado de trabalho tendem a elevar os rendimentos, embora os ganhos estejam sujeitos a retornos decrescentes. Este efeito é captado pelo sinal de positivo do coeficiente da variável experiência (EXPER) e pelo sinal negativo do coeficiente da variável experiência ao quadrado (EXPER ${ }^{2}$ ), seguindo a forma de $\mathrm{U}$ invertido ou côncava (parabólica), atingindo um pico próximo à idade média do indivíduo. O sinal positivo do termo de interação entre educação e experiência (EXPER $\times$ EDUC) indica que o indivíduo com maior escolaridade (devido suas maiores habilidades) tende a receber maior treinamento, acumulando mais capital humano (Berndt, 1991).

Os homens que trabalham no setor secundário e terciário auferem melhores rendimentos que os homens do setor primário (variável omitida). De acordo o Relatório sobre o Desenvolvimento Mundial (1995), a melhoria do salário real significa um aumento da produtividade da mão-de-obra dentro dos setores e um deslocamento de trabalhadores para os setores de maior produtividade, como a indústria e os serviços, que são setores que exigem maior escolaridade dos trabalhadores. Isto indica que nos setores secundário e terciário provavelmente o nível de escolaridade da mão-de-obra é mais elevado que o setor primário. Este fato é corroborado com um trabalho recente de Barros \& Mendonça (1995) que analisou a qualidade do emprego com ênfase no atributo educação, e constataram evidências de que trabalhadores mais qualificados são melhores remunerados, independentemente do ramo de atividade.

Os trabalhadores filiados a sindicatos obtêm rendimentos maiores em relação àqueles não-filiados, evidenciando o maior poder de barganha conferido aos trabalhadores em uma negociação salarial, quando se acham representados por um sindicato. 
Estudando os fatores determinantes dos salários relativos com base em levantamento de dados primários (fevereiro a junho de 1994) junto a trabalhadores na região metropolitana do Recife, Barros \& Barros (1995) mostram que a filiação a sindicatos tem influência positiva nos rendimentos, devido ao maior poder de barganha conferido aos trabalhadores. Segundo o estudo sobre o desenvolvimento mundial (1995), apesar de buscarem maior igualdade salarial para seus membros, os sindicatos tendem a elevar as disparidades entre os empregados sindicalizados e os não-sindicalizados.

Observa-se que os rendimentos dos trabalhadores do setor público são maiores que os rendimentos dos trabalhadores do setor privado ${ }^{29}$. Analisando a questão dos diferenciais dos salários entre o setor público e o setor privado, Vergara \& Wiltgen (1995) concluiram que, nos grupos de baixa escolaridade e com tempo de serviço superior a cinco anos, os salários do setor público superam os do setor privado.

Macedo (1995) examinou os salários nas empresas estatais brasileiras e privadas, de tamanho semelhante e atuando na mesma indústria, verificando que os salários nas empresas estatais superam os pagos pelas empresas privadas. De acordo com Chahad (1990) esta diferença não deveria existir sob o prisma teórico, porque a ocupação pública usufrui de condições de estabilidade não verificadas nas ocupações do setor privado, razão pela qual deveria prevalecer, como regra, um nivel de salários menor entre os funcionários públicos, como forma de compensar sua maior estabilidade.

Quase todos os países revelam disparidades regionais em seus dotes de recursos, renda e taxas de crescimento, que muitas vezes persistem ao longo do tempo, e o Brasil não é exceção à regra. Os coeficientes estimados para as regiões confirmam a

\footnotetext{
${ }^{29}$ Recente estudo do Ministério da Administração e Reforma do Estado concluiu que o servidor público federal de nivel executivo ganha em média $14 \%$ menos do que no setor privado. Por outro lado, o servidor público que exerce cargos operacionais, ganham cerca de $45 \%$ a mais do que no setor privado. Nos níveis superior e técnico/médio o servidor público ganha cerca de $5 \%$ e $3 \%$ menos do que o do setor privado, respectivamente.
} 
desigualdade. Os trabalhadores do Nordeste (região considerada mais pobre) possuem rendimentos inferiores aos das pessoas que trabalham no restante do país.

A raça também parece ser um fator discriminatório. Tomando como referência os trabalhadores de cor negra, verifica-se que os rendimentos são maiores para os individuos de cor branca e/ou parda.

O coeficiente da variável LAMBDA (inverso da razão de Mill) é estatisticamente significativo, mostrando que sua inclusão na estimação foi necessária para evitar o viés causado pela seletividade amostral.

O coeficiente de determinação $\left(R^{2}\right)$ não apresenta um valor muito elevado, porque os dados da pesquisa são individuais e a variabilidade é enorme, ou seja, é impossivel captar toda a variabilidade dos dados.

\subsection{Participação no Mercado de Trabalho - Mulheres}

Os resultados do modelo próbite [equação (11)] estimados pelo método de máxima verossimilhança são mostrados na Tabela 6 , em que a variável dependente assume valor igual a 1 se a mulher participa do mercado de trabalho ou 0 , caso contrário. O teste de razão de verossimilhança é altamente significativo e igual a $13368,51^{30}$. De uma amostra 73.033 mulheres, apenas 37.235 estão engajadas no mercado de trabalho.

Quase todos os coeficientes estimados do modelo próbite são significativos. A propensão de as mulheres trabalharem é maior quanto maior seu nível de escolaridade. Porém, a variável EXPER apresenta sinal contrário ao esperado. A variável EXPER ${ }^{2}$

\footnotetext{
${ }^{30}$ Este teste tem distribuição de qui quadrado com 21 graus de liberdade.
} 
indica a depreciação do capital humano, mostrando que à medida que a pessoa passa a ter mais experiência suas oportunidades de participar do mercado de trabalho aumentam até uma certa idade, a partir da qual suas possibilidades de engajamento no mercado de trabalho apresentam decréscimo.

Tabela 6. Resultados da equação próbite de participação no mercado de trabalho Mulheres.

\begin{tabular}{lcc}
\hline Variável & Coeficiente & Teste t \\
\hline CONSTANTE & 0,398 & $8,98^{\mathrm{a}}$ \\
EDUCAÇÃO & 0,096 & $33,17^{\mathrm{a}}$ \\
EXPER & $-0,004$ & $-2,21^{\mathrm{b}}$ \\
EXPER & $-0,0003$ & $-10,38^{\mathrm{a}}$ \\
EXPER X EDUC & $-0,001$ & $-14,98^{\mathrm{a}}$ \\
CHEFE & 0,37 & $-0,51^{\mathrm{a}}$ \\
CÔNJUGE & $-0,526$ & $-19,10^{\mathrm{a}}$ \\
FILHO & $-0,477$ & $-17,39^{\mathrm{a}}$ \\
EXP-MAR & $\mathbf{0 , 0 0 7}$ & $17,18^{\mathrm{a}}$ \\
EDU-MAR & $-0,008$ & $-6,98^{\mathrm{a}}$ \\
FILHO(A)0-2 & $-0,393$ & $-34,09^{\mathrm{a}}$ \\
FILHO(A)3-5 & $-0,187$ & $-17,45^{\mathrm{a}}$ \\
FILHO(A)6-12 & $\mathbf{0 , 0 1 4}$ & $2,38^{\mathrm{b}}$ \\
FILHA 13 & $\mathbf{0 , 0 9 6}$ & $11,22^{\mathrm{a}}$ \\
FILHO 13 & $-0,004$ & $-0,52$ \\
RNSAL & $-0,0006$ & $-19,07^{\mathrm{a}}$ \\
BRAMA & $-0,185$ & $-8,15^{\mathrm{a}}$ \\
PARDO & $-0,130$ & $-5,61^{\mathrm{a}}$ \\
NORTE & $-0,012$ & $-0,51$ \\
CENTRO-OESTE & 0,054 & $2,53^{\mathrm{b}}$ \\
SUL & $\mathbf{0 , 1 9 7}$ & $11,29^{\mathrm{a}}$ \\
SUDESTE & 0,097 & $7,31^{\mathrm{a}}$ \\
Razão Verossimilhança & $13368,51^{\mathrm{a}}$ & \\
\hline
\end{tabular}

Fonte: Dados da PNAD-1995.

${ }^{a}$ Significativo ao nivel de $1 \%$

${ }^{\mathrm{b}}$ Significativo ao nivel de $5 \%$

Nota: vide definição das variáveis na tabela 2. 
O coeficiente da variável EXP $x$ EDUC é negativo, mostrando que a importância dos anos de escolaridade da mulher é decrescente quando ela apresenta grande experiência na área de atuação, para obter uma colocação no mercado de trabalho (Kassouf, 1996).

Quanto maior for o número de filhos em idade pré-escolar, maior será a demanda de tempo em atividades domésticas, e menores as probabilidades de as mães ingressarem no mercado de trabalho, uma vez que filhos pequenos demandam maior tempo de cuidados maternos. Por outro lado, filhas em idade escolar diminuem a exigência de cuidados maternos. Além disso, podem auxiliar nas tarefas domésticas, contribuindo para aumentar o tempo disponivel das mulheres para se dedicarem a atividades extradomiciliares (facilitando a conciliação de atividades no mercado de trabalho e no domicílio), aumentando, assim, suas probabilidades de ingressarem no mercado de trabalho. Esta relação é visualizada pelos coeficientes positivos das variáveis FILHA $\geq 13$ e FILHO(A)6-12, e os coeficientes negativos das variáveis FILHO(A)0-2 e FILHO(A)3-5.

A educação do marido também afeta a inserção da mulher no mercado de trabalho, indicada pelo sinal negativo do coeficiente, ou seja, quanto mais elevado o nível de escolaridade do marido, maior seu rendimento e menor a participação da mulher no mercado de trabalho. A variável experiência do marido apresentou sinal positivo, indicando que a experiência no mercado de trabalho tem uma influência bem menor que a escolaridade sobre os rendimentos. Outro fator que contribui para o menor engajamento das mulheres no trabalho é a renda não-salarial, captado pelo sinal negativo de seu coeficiente.

Estes resultados são semelhantes aos do trabalho de Sedlacek \& Santos (1991) que, a partir da PNAD de 1984, estudaram a participação das esposas no mercado de trabalho, por intermédio de modelos próbite, e inferiram que a propensão de os cônjuges 
femininos trabalharem é maior: i) quanto mais elevado o seu nível de escolaridade; ii) quanto maior a idade dos filhos e menor o número destes; e, iii) quando a idade da mulher estiver entre 20 e 30 anos. Ramos \& Soares $(1995)^{31}$ ao estudarem a participação da mulher no mercado de trabalho, constataram que as famílias mais pobres apresentam as taxas mais baixas de participação das esposas no mercado de trabalho, devido principalmente ao baixo grau de escolaridade e ao elevado número de filhos em idade pré-escolar. Mulheres com melhores níveis de escolaridade têm acesso a melhores postos de trabalho e a rendimentos maiores, além de o custo de oportunidade do tempo dedicado a tarefas domésticas tornar-se elevado, sendo mais atrativa do ponto de vista econômico a contratação de pessoas para realização de tarefas domésticas, liberando a mulher com melhor nivel de escolaridade para o engajamento no mercado de trabalho.

Tiefenthaler (1989), em estudo sobre a participação feminina no mercado de trabalho no Brasil, argumentou que a escolaridade e a idade (utilizada como proxy para experiência) afetam positivamente a probabilidade da participação da mulher no mercado de trabalho, enquanto a renda não-salarial, rendimentos do marido (proxys usadas para medir a riqueza) e crianças em idades que demandem maiores cuidados maternos afetam negativamente esta. Analisando a oferta de trabalho feminina no Japão, Hill (1989) também concluiu que, quanto maior o número de crianças com menos de seis anos de idade e quanto mais elevados os rendimentos do marido, menor será a probabilidade de as mulheres nele ingressarem.

Com relação à posição na família, verifica-se na Tabela 6 que, se a mulher for o chefe do domicílio, sua probabilidade de participar do mercado de trabalho é maior que a das cônjuges e filhas. Este fato pode dar-se em virtude da ausência da figura do homem adulto no lar, ou por este não participar do mercado de trabalho. A entrada neste, das

\footnotetext{
${ }^{31}$ Os autores argumentam que as evidências empíricas diretas mostram que existe uma relação em forma de $U$ entre a participação das esposas no mercado de trabalho e a renda do marido, de tal forma que uma alta taxa de participação dos cônjuges femininos no mercado de trabalho é encontrada tanto para o caso de maridos com baixa renda quanto para o caso de maridos com alta renda, e uma pequena taxa para o caso de maridos com rendas intermediárias.
} 
mulheres chefes de familia assume importância vital no orçamento familiar. Esta constatação é também corroborada por Kassouf (1997).

Novamente, comprova-se na Tabela 6 a desigualdade regional existente no país; as regiões Centro-Oeste, Sudeste e Sul oferecem mais oportunidades de trabalho do que o Nordeste.

O sinal negativo das variáveis BRAMA e PARDO denotam que a probabilidade de a mulher de cor negra ingressar no mercado de trabalho é maior que a da de cor branca ou parda. Geralmente, os indivíduos de cor negra são originários de famílias com renda per capita mais baixa. Isto indica que seu engajamento no mercado de trabalho contribui para a elevação da renda familiar, reduzindo a incidência da pobreza em sua unidade familiar.

Kassouf (1993 e 1994), ao ajustar a equação de participação no mercado de trabalho e rendimentos para homens e mulheres, também concluiu que : i) os chefes têm maior probabilidade de participar no mercado de trabalho do que os filhos e/ou cônjuges; ii) a renda não-salarial afeta negativamente a participação no mercado de trabalho; iii) quanto maior a quantidade de crianças pequenas, menor a participação das mulheres no mercado de trabalho; e iv) anos adicionais de escolaridade e experiência aumentam a probabilidade de engajamento dos indivíduos no mercado de trabalho.

\subsection{Equação de Rendimentos - Mulheres}

Os resultados da equação dos rendimentos [equação (14)] para 37.235 mulheres que estão inseridas no mercado de trabalho são apresentados na Tabela 7. 
Tabela 7. Resultados da equação de rendimentos - Mulheres.

\begin{tabular}{lcc}
\hline \multicolumn{1}{c}{ Variável } & Coeficiente & Teste $-\mathrm{t}$ \\
\hline CONSTANTE & $\mathbf{- 1 , 6 6 9}$ & $-6,44^{\mathrm{a}}$ \\
EDUCAÇÃO & $\mathbf{0 , 1 3 0 9}$ & $59,41^{\mathrm{a}}$ \\
EXPER & $\mathbf{0 , 0 3 2}$ & $17,89^{\mathrm{a}}$ \\
EXPER & $-0,00038$ & $-12,23^{\mathrm{a}}$ \\
EXPER X EDUC & $\mathbf{- 0 , 0 0 0 5}$ & $-3,52^{\mathrm{a}}$ \\
SUDESTE & $\mathbf{0 , 4 4 0}$ & $33,49^{\mathrm{a}}$ \\
SUL & $\mathbf{0 , 3 1 5}$ & $16,17^{\mathrm{a}}$ \\
CENTRO-OESTE & $\mathbf{0 , 2 8 0}$ & $13,08^{\mathrm{a}}$ \\
NORTE & $\mathbf{0 , 2 8 1}$ & $10,92^{\mathrm{a}}$ \\
SINDIC & $\mathbf{0 , 3 2 0}$ & $30,90^{\mathrm{a}}$ \\
PRIVADO & $-\mathbf{0 , 1 4 1}$ & $-22,15^{\mathrm{a}}$ \\
SECUNDA & $\mathbf{0 , 2 9 6}$ & $6,52^{\mathrm{a}}$ \\
TERCIA & $\mathbf{0 , 2 1 2}$ & $4,24^{\mathrm{a}}$ \\
BRAMA & $\mathbf{0 , 1 7 6}$ & $9,74^{\mathrm{a}}$ \\
PARDO & $\mathbf{- 0 , 0 0 1}$ & $-0,32$ \\
LAMBDA & $\mathbf{0 , 1 1 6}$ & $7,06^{\mathrm{a}}$ \\
R & $\mathbf{0 , 4 3}$ & \\
TeSte - F & $\mathbf{1 8 7 9 , 8 2 ^ { \mathrm { a } }}$ & \\
\hline
\end{tabular}

Fonte: Dados da PNAD-1995.

a Significativo ao nível de $1 \%$

Nota: vide definição das variáveis na tabela 3 .

O sinal positivo do coeficiente da variável EXPER e o negativo da variável EXPER $^{2}$ indicam que anos adicionais de experiência no mercado de trabalho aumentam os rendimentos; porém, os ganhos provenientes dessa maior experiência estão sujeitos a retornos decrescentes. O coeficiente da variável EXPER x EDUC é negativo, mostrando que o efeito da escolaridade diminui quanto maior for a experiência.

Os setores secundário e terciário pagam melhores salários às mulheres que $\mathrm{o}$ setor primário. Este efeito é captado pelos sinais positivos dos coeficientes das variáveis que representam os ramos de atividade. 
Assim como os homens, as mulheres que trabalham no setor público desfrutam de um efeito positivo nos rendimentos quando comparadas às do setor privado. A filiação a sindicatos por parte das trabalhadoras também tem influência positiva nos rendimentos $^{32}$, captado pelo coeficiente da variável SINDIC, que apresentou sinal positivo.

As mulheres que trabalham e residem nas regiões Norte, Centro-Oeste, Sudeste e Sul apresentam diferencial positivo nos ganhos, se comparadas às da região Nordeste. Este resultado é observado através dos coeficientes positivos das variáveis que representam as regiões. No mercado de trabalho feminino, os rendimentos das trabalhadoras de raça branca ou amarela são maiores que os da de raça negra. Este resultado é corroborado por Tiefenthaler (1989), em que verificou que as mulheres casadas e solteiras residentes na região Nordeste auferem rendimentos inferiores quando comparadas com outras regiões, assim como as mulheres de cor negra quando comparadas com as de cor branca. Esta evidência parece confirmar que pode existir correlação entre composição racial e regiões com melhores salários, já reconhecida por alguns autores (Barros \& Mendonça, 1995).

Estudando os trabalhadores do setor privado e residentes em regiões metropolitanas do Brasil, a partir de dados da PNAD de 1989, Cavalieri \& Fernandes (1995) constataram que os rendimentos dos homens são superiores aos das mulheres (apesar de os homens apresentarem menor nível educacional), como também os rendimentos dos indivíduos de cor branca são maiores que os dos indivíduos de cor negra. Essas evidências foram também encontradas para cada umas das regiões do país.

\footnotetext{
${ }^{32}$ Um estudo utilizando dados salariais do México de 1989 concluiu que, no setor não sindicalizado, os homens ganhavam $17,5 \%$ mais do que as mulheres com mesmas habilidades e experiência, mas não encontrou um diferencial salarial significativo entre homens e mulheres no setor sindicalizado (Relatório sobre o desenvolvimento mundial. 1995).
} 
Observa-se que a inclusão da variável LAMBDA na regressão foi necessária para evitar problemas de tendenciosidade que a seletividade amostral poderia gerar na estimação dos coeficientes.

\subsection{Retornos aos Investimentos em Escolaridade e Experiência}

Considere a seguinte equação:

$$
\ln \mathrm{Y}=\alpha+\beta_{l} \exp +\beta_{2} \exp ^{2}+\beta_{3} \text { educ }+\beta_{4} \operatorname{educ} \exp +\mathrm{u}_{i}
$$

onde Y é o rendimento por hora, exp é experiência e educ é educação.

Por várias razões discutidas anteriormente, admite-se que o estoque de capital humano dos indivíduos aumente após o término do período de educação formal e ingresso no mercado de trabalho. Espera-se que os rendimentos dos indivíduos resultantes de anos adicionais de experiência apresentem retornos decrescentes, uma vez que eles devem aumentar no início da atividade profissional, devido aos ganhos de produtividade agregados à acumulação de experiência no mercado de trabalho, e, em seguida, diminuir, à medida que se aproxima o término da atividade profissional, devido a efeitos causados pela obsolescência e depreciação do estoque de capital humano. A teoria do capital humano também sugere que o rendimento é linear em escolaridade, e que o efeito da experiência sobre os rendimentos não depende somente da experiência, mas também da educação, por isto uma interação é adicionada ${ }^{33}$.

Para captar o efeito da escolaridade sobre os rendimentos ${ }^{34}$, obtêm-se a derivada parcial,

\footnotetext{
${ }^{33}$ Ver Berndt (1991) e Willis (1986).

${ }^{34}$ Variável operacionalizada em logaritmo
} 


$$
\frac{\partial \ln Y}{\partial \mathrm{educ}}=\beta_{3}+\beta_{4} \exp
$$

e para o efeito da experiência sobre os rendimentos,

$$
\frac{\partial \ln \mathrm{Y}}{\partial \exp }=\beta_{1}+2 \beta_{2} \exp +\beta_{4} \operatorname{educ}
$$

Considerando, por exemplo, a equação dos rendimentos das mulheres (Tabela 7). O efeito da escolaridade sobre os rendimentos é:

$$
\frac{\partial \ln Y}{\partial \mathrm{educ}}=0,1309-0,0005 \times \exp
$$

e considerando 4 anos de experiência no mercado de trabalho, temos:

$$
\frac{\partial \ln Y}{\partial \mathrm{educ}}=0,1309-0,0005(4)=0,129
$$

O efeito da experiência sobre os rendimentos, é:

$$
\frac{\partial \ln Y}{\partial \exp }=0,032-2 \times 0,00038 \times \exp -0,0005 \times \text { educ }
$$

Encontram-se os seguintes valores ao considerar 8 anos de escolaridade: para 4 anos de experiência, $\frac{\partial \ln Y}{\partial \exp }=0,02496=2,496 \%$; $\quad$ para $\quad 8 \quad$ anos de experiência, $\frac{\partial \ln Y}{\partial \exp }=0,02192=2,192 \% ; \quad$ e $\quad$ para $\quad 12 \quad$ anos $\quad$ de experiência, $\frac{\partial \ln Y}{\partial \exp }=0,01888=1,888 \%$.

Para calcular o número de anos de experiência que maximiza os rendimentos, iguala-se a zero a equação (16) e isola-se a variável experiência em um determinado nível de escolaridade. Considerando 4 anos de escolaridade obtêm-se: 


$$
\begin{aligned}
& \frac{\partial \ln Y}{\partial \exp }=0,032-2 \times 0,00038 \times \exp -0,0005 \times \text { educ } \\
& =0,032-2 \times 0,00038 \times \exp -0,0005 \times(4) \\
& \frac{\partial \ln Y}{\partial \exp }=0,03-0,00076 \times \exp =0 \\
& \text { Logo, } \exp =39,47 \cong 39 \text { anos. }
\end{aligned}
$$

A Tabela 8 mostra os retornos à escolaridade para homens e mulheres. Por exemplo, homens que têm 12 anos de experiência no mercado de trabalho, podem elevar seus rendimentos em $10,53 \%$ por ano adicional de escolaridade.

Tabela 8. Retornos à escolaridade, em porcentagem.

\begin{tabular}{ccc}
\hline & Homens & Mulheres \\
\cline { 2 - 3 } Experiência & & \\
\hline 4 & 9,89 & 12,90 \\
8 & 10,21 & 12,70 \\
12 & 10,53 & 12,50 \\
\hline
\end{tabular}

Fonte: Dados da PNAD-1995.

Verifica-se que os retornos à escolaridade são positivos, e os das mulheres são bem maiores que dos homens, e que declinam com os anos de experiência. Por outro lado, quanto maior o número de anos de experiência, mais elevados serão os retornos para os homens. $\mathrm{O}$ aumento do retorno com o aumento da escolaridade provavelmente está relacionado à escassez relativa de trabalhadores qualificados. Quando existe uma grande demanda ou pouca oferta de trabalhadores, a taxa de retorno é mais elevada, e quando existe relativo excesso de pessoal qualificado ou quando sua procura é pequena, essa taxa tende a decrescer (Relatório sobre o desenvolvimento mundial, 1995). 
Psacharoupolos (1985) também concluiu que as mulheres, nos países em desenvolvimento, apresentam uma taxa de retorno à escolaridade (15\%) que supera a dos homens em quatro pontos percentuais. Valores bem menores para os retornos à escolaridade foram calculados por Byron \& Manaloto (1990) para homens na China, e a taxa de retorno para as mulheres foi inferior à dos homens em 9\%. Ram (1996), trabalhando com dados sobre a renda-per-capita dos trabalhadores e nível de escolaridade médio da força de trabalho de vários países calculou uma taxa de retorno próxima a 13\%. Resultados estimados por Sahn \& Alderman (1988) revelam que as taxas de retornos foram maiores para as trabalhadoras no Sri Lanka residentes tanto na zona urbana quanto na rural.

Ao avaliar homens e mulheres colombianos que participavam do mercado de trabalho, Psacharopoulos \& Velez (1992) verificaram que um ano a mais de escolaridade eleva os rendimentos em $9,8 \%$ e $9,4 \%$, respectivamente.

A Tabela 9 apresenta os retornos à experiência, para homens e mulheres. Os resultados mostram que os retornos à experiência também são positivos e bem menores que os retornos à escolaridade. Considerando as mulheres com 4 anos de escolaridade e 12 anos de experiência, constata-se que seus rendimentos podem elevar em $2,08 \%$ por ano adicional de experiência no mercado de trabalho.

As mulheres apresentam retornos decrescentes com anos adicionais de escolaridade e experiência (de 4 para 12 anos). Enquanto que, para os homens, os retornos diminuem com o aumento da experiência e se elevam com o nível de escolaridade. Observa-se que os retornos para homens e mulheres têm valores próximos, em níveis de escolaridade mais baixos. Porém, quando os anos de escolaridade aumentam, os homens apresentam maiores retornos à experiência. 
Tabela 9. Retornos à experiência, em porcentagem.

\begin{tabular}{|c|c|c|}
\hline \multirow[b]{2}{*}{ Experiência } & Homens & Mulheres \\
\hline & & \\
\hline & \multicolumn{2}{|c|}{ Escolaridade $=4$} \\
\hline 4 & 2,52 & 2,69 \\
\hline 8 & 2,32 & 2,39 \\
\hline \multirow[t]{2}{*}{12} & 2,12 & 2,08 \\
\hline & \multicolumn{2}{|c|}{ Escolaridade $=8$} \\
\hline \multirow{4}{*}{$\begin{array}{c}4 \\
8 \\
12\end{array}$} & 284 & 249 \\
\hline & 2,64 & 2,19 \\
\hline & 2,44 & 1,88 \\
\hline & \multicolumn{2}{|c|}{ Escolaridade $=12$} \\
\hline 4 & 3,16 & 2,29 \\
\hline 8 & 2,96 & 1,99 \\
\hline 12 & 2,76 & 1,68 \\
\hline
\end{tabular}

Fonte: Dados da PNAD-1995

Hill (1989), ao calcular os retornos à experiência para as mulheres casadas no Japão, também verificou valores próximos a $3 \%$ por ano adicional de experiência e sempre menores que os retornos à escolaridade.

O número de anos de experiência que maximiza a função rendimentos, considerando 4 anos de escolaridade, é de 54 e 39 anos de experiência, respectivamente, para homens e mulheres. Isto significa que a idade em que os homens atingirão o pico dos seus rendimentos é superior à das mulheres.

Kassouf (1997), com base em dados da Pesquisa Nacional sobre Saúde e Nutrição (1989), estimou os retornos à experiência para homens e mulheres dos setores formal e informal. Os valores estimados mostraram que os retornos à experiência para homens variou de $1,39 \%$ a $5,6 \%$ e, para as mulheres estes retornos variaram de $1,35 \%$ a $3,8 \%$.

Kassouf (1996), também a partir de dados da Pesquisa Nacional sobre Saúde e Nutrição (1989), estudou os retornos à escolaridade e a experiência para trabalhadores 
do setor urbano. Os valores encontrados mostraram que mulheres do setor urbano apresentaram maiores retornos à escolaridade que os homens (variando entre $16,6 \% \mathrm{e}$ $15,7 \%$, e $21,6 \%$ e $19,6 \%$, respectivamente, para homens e mulheres). E que os anos de experiência que maximizam os rendimentos são menores para as mulheres se comparados com os homens (33 e 36, respectivamente para mulheres e homens, considerando 4 anos de escolaridade)

Ao comparar os retornos à escolaridade entre as mulheres casadas e solteiras engajadas nos diversos mercados de trabalho (formal, informal e autônomos), Thiefenthaler (1989) estimou retornos maiores para as portadoras de diploma de curso superior (entre 12 e 16,2\%) quando comparados aos das que cursaram o primário (entre $10,5$ e $15,4 \%)$.

Leal \& Werlang (1991), estudando retornos à escolaridade entre homens participantes do mercado de trabalho residentes no setor urbano no Brasil, encontraram retornos à escolaridade maiores para quem possuía o curso primário $(16,2 \%)$, por outro lado, as pessoas com 4 a 8 anos de escolaridade (ginásio) apresentaram retornos sempre menores (aproximadamente 10\%) quando comparadas a trabalhadores com segundo grau (acima de 15\%) ou nível universitário $(14,3 \%)$.

Vieira (1997), a partir de dados da PNAD-1995, estimou uma taxa de retorno por ano de estudo sempre maior para as mulheres [tanto para empregadores $(5,7 \%)$, como para trabalhadores do setor formal (aproximadamente 17\%) e informal (aproximadamente 9,5\%)], se comparados com os homens [empregadores $(5,5 \%)$, trabalhadores do setor formal (aproximadamente 14\%) e informal (4,5\%)]. O número de anos de experiência que maximiza a função rendimentos apresentou valores bastante próximos, tanto entre homens e mulheres, quanto no setor formal (36 e 35 anos, respectivamente, para homens e mulheres) e informal ( 38 anos para ambos os sexos). 
Como dito anteriormente, a desigualdade nos rendimentos pode estender-se por dimensões regionais. Os recursos disponíveis (fisicos, humanos e financeiros), a falta de investimentos e a renda, podem ter efeitos sobre os tipos de firmas e atividades econômicas predominantes em determinada região, que influenciam no mercado de trabalho e, consequentemente, nos rendimentos.

Com o intuito de melhor comparar as taxas de retorno à educação e à experiência, entre as diversas regiões do país, a equação de participação no mercado de trabalho e dos rendimentos para homens e mulheres foi estimada separadamente para cada uma das regiões ${ }^{37}$. Posteriormente, calcularam-se os retornos à escolaridade e à experiência. As Tabelas 10 e 11 mostram os retornos à escolaridade e à experiência, respectivamente. Observa-se que os retornos apresentam valores que variam de região para região.

Constata-se que os homens apresentam retornos à escolaridade menores que os das mulheres em todas as regiões do país. Além disso, os retornos à escolaridade são, no mínimo, mais que o dobro dos retornos à experiência. A região Norte e a Centro-Oeste apresentam os maiores retornos à escolaridade para as mulheres e a região Sul e Sudeste para os homens. Os resultados também indicam que os retornos à escolaridade mais baixos são para os homens residentes na região Norte e Nordeste.

\footnotetext{
${ }^{37}$ Nos anexos estão apresentadas as equações de participação no mercado de trabalho e de rendimentos utilizadas para calcular todas as tabelas desta seção.
} 

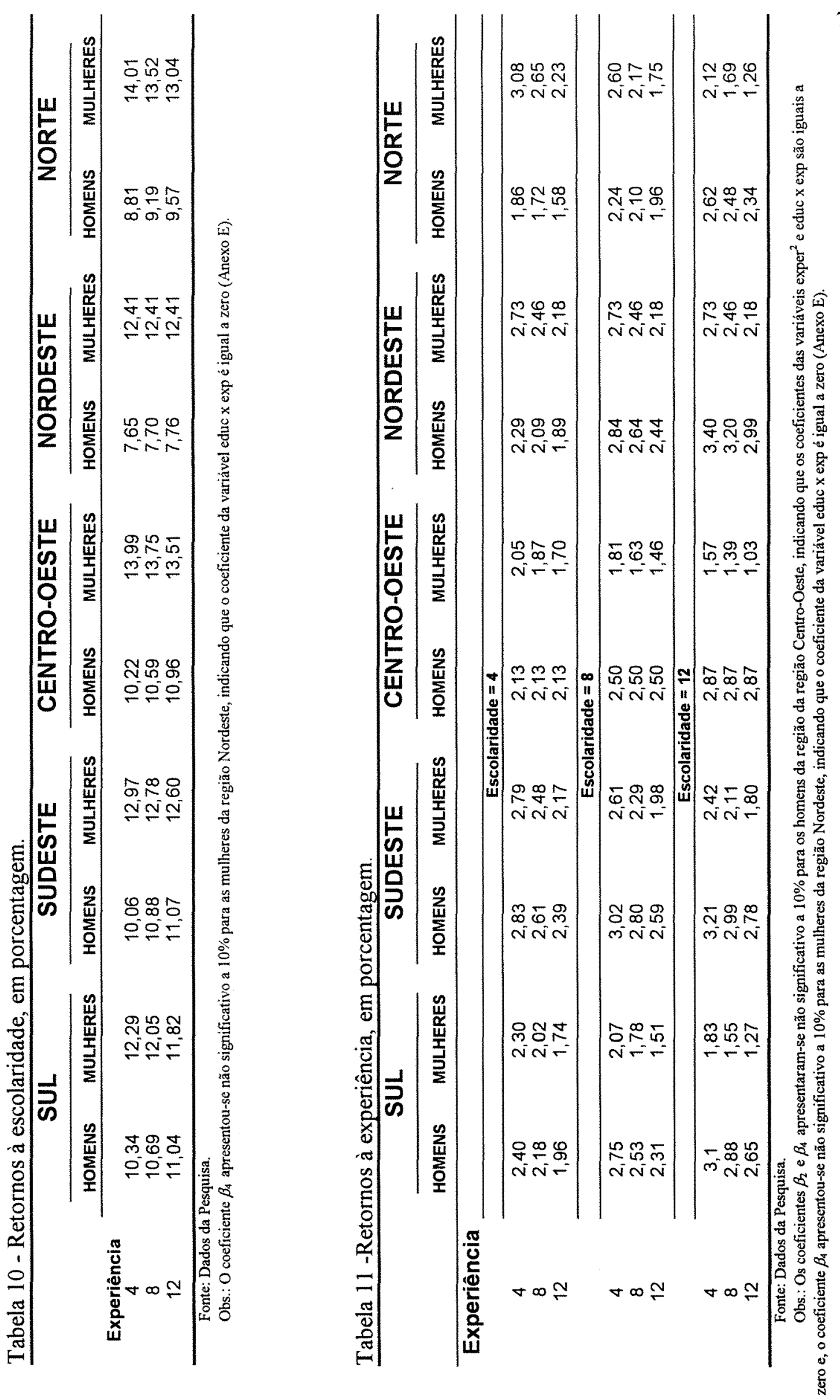
O número de anos de experiência que maximiza a função rendimentos sempre apresenta valores inferiores para as mulheres da região Norte e para os homens da região Sul, considerando 4 anos de escolaridade, e 32 e 36 anos de experiência, respectivamente.

As taxas de retorno à experiência estimadas para as mulheres quase sempre mostram valores menores do que para os homens [exceto a região Nordeste (para os trabalhadores com 4 anos de escolaridade) e a região Norte para trabalhadores com 4 e 8 anos de escolaridade], e decrescem com os anos de escolaridade, ao contrário do que acontece no caso da mão-de-obra masculina. Os homens residentes na região Norte são os que apresentam os valores mais baixos de retorno à experiência; por outro lado, as mulheres da região Norte mostram maior retorno, juntamente com as da região Sudeste. Os homens que apresentam os retornos à experiência maiores são os residentes na região Sudeste.

Nos últimos anos, formou-se um imenso debate sobre o papel do Estado como empregador. As finanças públicas têm-se deteriorado em anos recentes, e a questão do funcionalismo e dos gastos com pessoal vem causando certa polêmica, pois, grande parte das receitas é destinada a pagamento dos funcionários, diminuindo a capacidade do Estado em fazer investimentos nas áreas sociais (saúde, educação e segurança). Nos setores públicos e privado existem peculiaridades institucionais de um lado e princípios de mercado de outro, que influenciam os diferenciais de rendimentos dos trabalhadores. Tentando investigar a existência desses possíveis diferenciais, calcularam-se as taxas de retorno à experiência e à escolaridade entre ambos os setores.

Os retornos à escolaridade para o setor público e privado são mostrados na Tabela 12. Observa-se que os retornos dos trabalhadores do setor público são maiores que os dos que atuam no setor privado, e os retornos para as mulheres são, nos dois setores, maiores que os constatados para os homens. Esse diferencial positivo nos 
A Tabela 13 mostra os retornos à experiência para os setores público e privado.

Tabela 13 - Retornos à experiência, em porcentagem.

\begin{tabular}{|c|c|c|c|c|}
\hline \multirow[b]{3}{*}{ Experiência } & \multicolumn{2}{|c|}{ PÚBLICO } & \multicolumn{2}{|c|}{ PRIVADO } \\
\hline & Homens & Mulheres & Homens & Mulheres \\
\hline & & & & \\
\hline \multirow{4}{*}{$\begin{array}{c}4 \\
8 \\
12\end{array}$} & \multicolumn{4}{|c|}{ Escolaridade $=4$} \\
\hline & 2,02 & 3,03 & 3,01 & 1,88 \\
\hline & 1,86 & 2,68 & 2,76 & 1,70 \\
\hline & 1,70 & 2,33 & 2,51 & 1,52 \\
\hline \multirow{5}{*}{$\begin{array}{c}4 \\
8 \\
12\end{array}$} & \multicolumn{4}{|c|}{ Escolaridade $=8$} \\
\hline & 2,21 & 2,70 & 3,42 & 1,93 \\
\hline & 2,06 & 2,35 & 3,16 & 1,75 \\
\hline & 1,90 & 2,01 & 2,90 & 1,57 \\
\hline & \multicolumn{4}{|c|}{ Escolaridade $=12$} \\
\hline 4 & 2,41 & 2,40 & 3,71 & 1,99 \\
\hline 8 & 2,25 & 2,05 & 3,45 & 1,81 \\
\hline 12 & 2,10 & 1,70 & 3,21 & 1,63 \\
\hline
\end{tabular}

Fonte: Dados da PNAD-1995.

Os retornos à experiência observados para os homens que trabalham no setor privado são superiores aos retornos para os homens do setor público. Já os retornos à experiência dos homens no setor público são, de modo geral, menores que os das mulheres que trabalham no setor público. As mulheres do setor privado apresentam retornos à experiência, quase sempre, duas vezes menores que os dos homens. Este resultado mostra que a experiência dos homens no mercado de trabalho é bastante valorizada pelo setor privado.

O pico da função de rendimentos ocorre com maior número de anos de experiência no setor privado em relação ao setor público, quando consideramos as mulheres. Por outro lado, os homens que trabalham no setor privado apresentam menor número de anos de experiência que os trabalhadores do setor público. Os valores calculados no setor público para homens e mulheres foram, respectivamente (considerando 4 anos de escolaridade) 55 e 39 anos de experiência, e, no setor privado, 52 e 46 anos de experiência. 
Outro aspecto responsável pela existência de diferenciação de salários é a ação dos sindicatos. Os sindicatos exercem a função de representantes dos trabalhadores, organizando-os em uma entidade única cujo poder de barganha se equipara ao dos empregadores. Para averiguar se a organização sindical implica em diferenciação dos trabalhadores, são calculados as taxas de retorno para os sindicalizados e os não sindicalizados.

A Tabela 14 mostra que as mulheres apresentam retornos à escolaridade sempre maiores que os dos homens, tanto para o caso dos individuos sindicalizados como para os não-sindicalizados. Ademais, os trabalhadores sindicalizados apresentam retornos maiores se comparados aos não-sindicalizados. Estas evidências parecem confirmar a hipótese de que os sindicatos realmente influem positivamente na valorização dos trabalhadores.

Tabela 14 - Retornos à escolaridade, em porcentagem

\begin{tabular}{|c|c|c|c|c|}
\hline \multirow{3}{*}{ Experiência } & \multicolumn{2}{|c|}{ SINDICALIZADO } & \multicolumn{2}{|c|}{ NÄO-SINDICALIZADO } \\
\hline & Homens & Mulheres & Homens & Mulheres \\
\hline & & & & \\
\hline 4 & 12,09 & 14,36 & 9,25 & 12,36 \\
\hline 8 & 12,18 & 14,04 & 9,65 & 12,19 \\
\hline 12 & 12,26 & 13,72 & 10,07 & 12,03 \\
\hline
\end{tabular}

Fonte: Dados da PNAD-1995.

Sachs \& Larrain (1995) afirmam que quase todos os estudos chegaram à conclusão de que os sindicatos tendem a aumentar os salários reais dos seus membros e a baixar o nível de emprego dos setores sindicalizados. A presença de sindicatos também afeta a maneira pela qual a economia responde às crises: se há uma crise e um mercado competitivo, a tendência é a queda dos salários reais. Porém, em um setor sindicalizado o resultado pode ser um salário real constante para os membros dos sindicatos e queda do salário real para os não filiados. 
A Tabela 15 mostra os retornos à experiência para os trabalhadores sindicalizados e não-sindicalizados.

Tabela 15 - Retornos à experiência, em porcentagem.

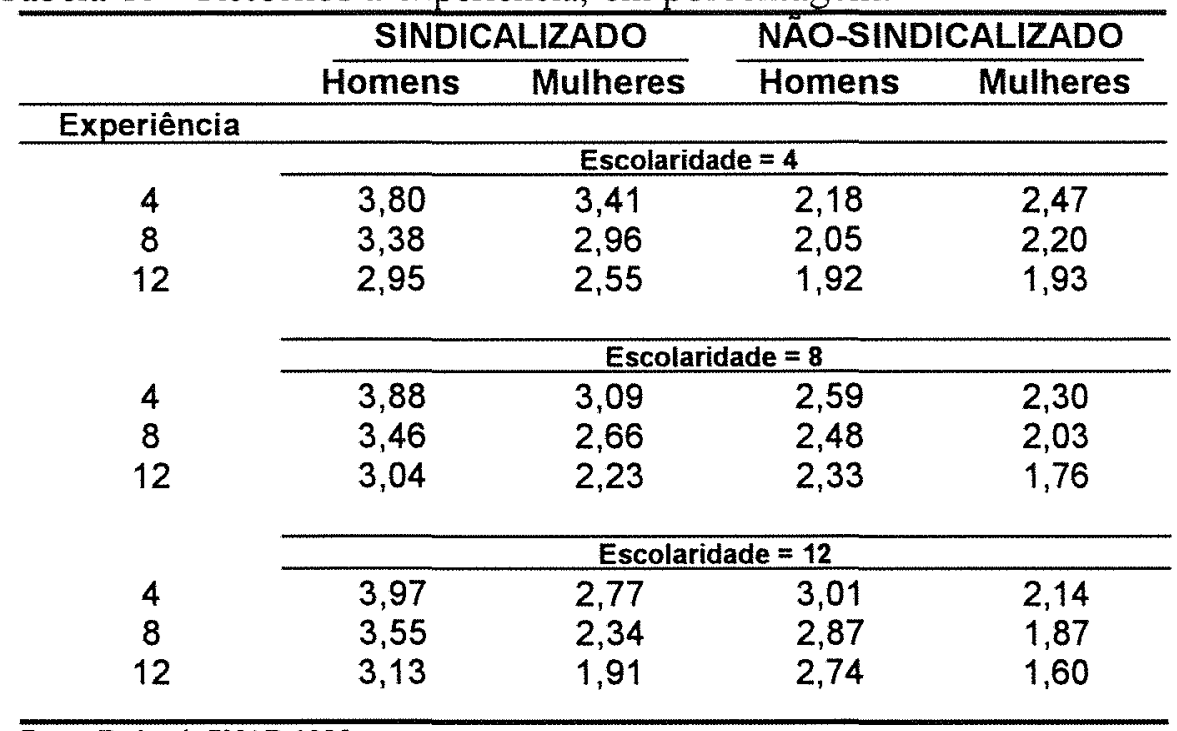

Fonte: Dados da PNAD-1995.

Verifica-se que os retornos à experiência para os trabalhadores sindicalizados são sempre maiores do que os registrados para os não sindicalizados. É interessante observar que as mulheres não-sindicalizadas, com níveis de escolaridade mais baixos (4 anos), apresentam retornos à experiência maiores que os homens. O número de anos de experiência que maximiza a função de rendimentos foi, para homens e mulheres sindicalizados (considerando 4 anos de escolaridade), respectivamente, 40 e 36 anos, e, para os não-sindicalizados, 69 e 40 anos de experiência. Isso indica que os trabalhadores sindicalizados têm possibilidade maior de atingir o rendimento máximo com menos idade do que os não-sindicalizados; principalmente os homens, os quais apresentam uma diferença significativa no número de anos de experiência necessários a maximizar os rendimentos. 


\section{CONCLUSÕES}

As evidências empíricas mostram que a educação e a experiência têm efeitos positivos sobre a probabilidade de participação dos indivíduos no mercado de trabalho. Os novos processos de organização do trabalho, a incorporação de novas tecnologias, a globalização dos mercados são alguns dos fenômenos que determinam o aumento geral da competitividade externa em todos os mercados. Isso implica numa crescente demanda por mão-de-obra cada qualificada apta para lidar com a inovação contínua e para os aumentos da produtividade.

Quanto maior a qualificação educacional, maiores as possibilidades do trabalhador integrar-se as novas exigências do mercado de trabalho, aumentando suas habilidades, através de treinamentos frequentes, melhorando sua empregabilidade. Pessoas com baixa qualificação terão dificuldades em obter uma colocação no mercado de trabalho.

Existem outros fatores que colaboram para a explicação da participação das pessoas no mercado de trabalho tais como: número de filhos e renda não-salarial. A probabilidade de participação dos individuos no mercado de trabalho cresce com o aumento do número de filhos, em conseqüência da maior exigência de renda; e, quanto maior sua renda não-salarial, menor sua necessidade de engajamento no mercado de trabalho. Observase também que, se o indivíduo for o chefe do domicílio, sua probabilidade de participar da força de trabalho é maior que a dos cônjuges e/ou dos filhos, denotando sua importância no sustento dos membros da família. 
Com relação às mulheres, verifica-se também outros dois condicionantes que determinam sua participação no mercado de trabalho: número de filhos em idade pré-escolar e renda do marido. Filhos pequenos exigem maior demanda por cuidados maternos; por outro lado, filhos em idade escolar necessitam de menor tempo da mulher dedicado à função materna e, além disso, as filhas adolescentes podem auxiliar nos afazeres domésticos, contribuindo para aumentar o tempo disponível das mulheres para se dedicarem a atividades extradomiciliares, (aumentando sua probabilidade de participação na força de trabalho). A implantação de infra-estrutura de serviços que visem a substituir o tempo dedicado à função materna, facilitaria o ingresso das mulheres no mercado de trabalho. Sabe-se que a renda do marido é de importância fundamental no orçamento familiar. Por causa disso, a taxa de participação das mulheres no mercado de trabalho tem uma relação inversa com a renda do marido, como foi evidenciado no presente trabalho.

Escolaridade e experiência são fatores importantes, do ponto de vista do trabalhador, para a determinação dos diferenciais de rendimentos. Como proposto pela teoria do capital humano, os investimentos em educação em um sentido amplo (incluindo treinamento) acarretariam o aumento da produtividade do fator trabalho. Ademais, características inerentes ao mercado (filiação a sindicatos, setor de emprego, região, etc.) e aos indivíduos (raça, sexo, etc.) também interferem na formação dos rendimentos, como se observa nos resultados encontrados na presente dissertação.

A educação, como visto, desempenha papel fundamental na determinação da renda dos trabalhadores e na participação no mercado de trabalho. Para o país conseguir dar um salto em direção ao desenvolvimento, é necessário investir em educação, preparando o trabalhador para uma economia com tecnologias cada vez mais sofisticadas. Os retornos à escolaridade, estimados nesta pesquisa, mostram que o Brasil é um país onde os rendimentos são bastante sensíveis ao nível educacional do trabalhador. Uma política educacional que conseguisse efetivamente elevar o nível médio de escolaridade, diminuindo o grau de desigualdade educacional, poderia ter impacto sobre o crescimento econômico via 
aumento do capital humano, e redução da desigualdade de renda (uma das mais elevadas do mundo).

A redução das disparidades nos rendimentos dos trabalhadores passa também por uma alocação ótima dos recursos provenientes de políticas educacionais e, para tanto, é necessário conhecer o comportamento da distribuição e a participação da escolaridade como elemento determinante da renda do trabalho

A função do Estado não é buscar garantias para a igualdade de renda entre os indivíduos, mas sim gerar a igualdade de oportunidades. Seu principal objetivo é assegurar, ao maior número de pessoas, as condições iniciais de educação e formação profissional, para que possam desenvolver todo seu potencial econômico, colaborando para a geração de riqueza. Ao fazer isso, o Estado não estará apenas melhorando indiretamente a distribuição de renda, mas contribuirá também para a elevação do nível de eficiência do sistema econômico, ao permitir que indivíduos possam ser efetivamente mobilizados para a geração de riquezas, alavancando suas aspirações.

Como sugestão para pesquisas futuras, seria interessante avaliar os retornos aos investimentos em capital humano, ao longo do tempo, pois poderia responder se a expansão educacional afetaria estes retornos. Seria também interessante avaliar qual nível de educação (primário, secundário ou terciário) apresenta maiores retornos, indicando para o Estado como deve ser a melhor alocação de recursos dentro da educação. 


\section{REFERÊNCIAS BIBLIOGRÁFICAS}

ALBUQUERQUE, R. C. (coord). O Brasil social: realidade, desafios, opções. Rio de Janeiro: IPEA, 1993. 544p.

ALVES, E. L. G.; SOARES, F. V. Ocupação e Escolaridade: tendências recentes na grande São Paulo. Rio de Janeiro: IPEA, 1996 (Texto para discussão, 428).

ALVES, E. R. de A. Programa de treinamento: carreira de pesquisador. In Coletânea de trabalhos sobre a Embrapa. Brasília: Embrapa/DIB, p. 73-80, 1980 (Documentos, v. 1),

AMADEO, E.; CAMARGO; J. M, GONZAGA, G.; BARROS, R. P., MENDONÇA, R. $S$. P. de. A natureza e o funcionamento do mercado trabalho brasileiro desde 1980. Rio de Janeiro: IPEA, 1994 (Texto para discussão, 353).

ANDERSON, L. Rate of Return to Human Capital: A test using El Salvador data. American Economic Review, v. 70, n. 2, p. 138-141, May 1980.

ANGRIST, J. D. The economic returns to schooling in the West Bank and Gaza Strip. The American Economic Review, v. 85, n. 5, p. 1065-1087, December 1995

AVILA, A. F. D.; BORGES-ANDRADE, J. E.; IRIAS, L. J. M. Formação do Capital Humano e retorno dos investimentos em treinamento na Embrapa. Brasilia: Embrapa/DID, 1983. 
AZEVEDO, P. F. Esforço tecnológico através de investimentos em capital humano nas empresas do setor de bens de capital brasileiro. São Paulo, 1992. 139p. Dissertação (Mestrado) - Faculdade de Economia e Administração, Universidade de São Paulo.

BARROS, A. R.; BARROS, M. R. Fatores determinantes dos salários relativos: um estudo empírico com dados primários. In: Encontro Nacional de Economia, 23, Salvador. Anais. Brasilía:ANPEC, 1995. v. 1, p. 43-57.

BARROS, R. P.; REIS, J. G. A. Desigualdade salarial e distribuição de educação: a evolução das diferenças regionais no Brasil. Pesquisa e Planejamento Econômico, v. 20, n. 3, p. 415-478, dez. 1990.

BARROS, R. P. de.; MACHADO, A. F.; MENDONÇA, R. S. P. A desigualdade da pobreza: estratégias ocupacionais e diferenciais por genêro. Rio de Janeiro: IPEA, 1997 (Texto para discussão, 453).

BARROS, R. P. de.; MENDONÇA, R. S. P. de. Os determinantes da desigualdade no Brasil. Rio de Janeiro: IPEA, 1995 (Texto para discussão, 377).

BARROS, R. P. de., MENDONÇA, R. S. P. de. Determinantes da participação de menores na força de trabalho. Rio de Janeiro: IPEA, 1990 (Texto para discussão, 200).

BARROS, R. P. de.; LAM, D. Income inequality, inequality in education, and children's attainment in Brazil. Rio de Janeiro: IPEA, 1993 (Texto para discussão, 294).

BECKER, G. S. Human capital. New York. NBER, 1964 
BERNDT, E. R. The practice of econometrics: classic and contemporary. Reading: Addison-Wesley, 1991. 702p

BLAUG, M. Jacob Mincer, schooling, experience and earnings Reviews. Economic Development and Cultural Change, v. 25, n. 1, p. 166-171, October 1976.

BROWN, R. S.; MOON, M.; ZOLOTH, B. S. Incorporating occupational attainment in studies of male-female earnings differentials. Journal of Human Resources, v. 15, n. 1, p. 3-28, fall 1980 .

BYRON, R. P. ; MANALOTO, E. Q. Returns to Education in China. Economic Development and Cultural Change. v. 38, n. 4, p. 783-795, July 1990,

CAVALIERI, C. H.; FERNANDES, R. Diferenciais salariais por gênero e cor: uma comparação entre as regiões metropolitanas. In: Encontro Nacional de Economia, 23, Salvador, 1995. Anais. Brasília:ANPEC, 1995. v. 1, p. 363-381.

CASTRO, C. de M. Investimento em educação no Brasil: comparação de três estudos. Pesquisa e Planejamento Econômico. v. 1, n. 1, p. 141-152, jun. 1971.

CHAHAD, J. P. Z. Emprego e salários na administração pública brasileira: evidências da década de 80. Revista Brasileira de Economia. v. 44, n. 4, p. 551-573. jul.set. 1990 .

CONCEIÇÃO, J. C. P. R. A educação e os seus efeitos sobre a produção agrícola. 1995. (mimeo). 
CRAWFORD, R. Na era do capital humano: o talento, a inteligência e o conhecimento como forças econômicas, seu impacto nas empresas e nas decisões de investimento. São Paulo: Atlas, 1994. 186p.

Educação nas Empresas. Folha de São Paulo, Empregos 1, São Paulo, 07 dez., 1997, p. $1-1$.

FUNDAÇÃO INSTITUTO BRASILEIRO DE GEOGRAFIA E ESTATÍSTICA Indicadores Sociais: uma analise da década de 1980: Rio de Janeiro. IBGE, 1995. $361 \mathrm{p}$

GAAG, van der J.; VIJVERBERG, W. Wage determinants in Côte d'Ivoire: Experience, Credentials, and Human Capital. Economic Development and Cultural Change, $v$. 37, n. 2, p. 371-382, January 1989.

GIBBON., V. H. Taxas de retorno dos investimentos em educação no Brasil: uma análise desagregada. Revista Brasileira de Economia. v. 29, n. 3, p. 109-133. jul-set. 1975.

GLEWWE, P. The relevance of standard estimates of return to schooling for education policy: a critical assesnment. Economic Development and Cultural Change, v. 51, n. 1, p. 267-290, October 1996.

GRILICHES, Z. Estimating the returns to schooling: some econometric problems. Econometrica, v. 45, n. 1, p. 1-22, January 1977.

GREENE; W. Econometric Analysis. Macmillan Publishing Company. 1993.

HECKMAN, J. J. Sample Selection Bias as a Specification Error. Econometrica, v.45, n.1, p. 153-161. January 1979. 
Sample Selection Bias as a Specification Error. In: Smith, J. P. Female

Labor Suply: Theory and Estimation. New Jersey: Princeton University Press. 1980.

HENDERSON, J. W. Earnings functions for the self-employed. Journal of Development Economics, v. 41, n. 1, p. 97-102, June 1983.

HILL, M. A. Female labor suply in Japan: implications of the informal sector for labor participation and hours of work. Journal of Human Resources, v. 24, n. 1, p. 142165 , winter 1989.

KASSOUF, A. L. Estimation of health demand and health production for children in Brasil. St. Paul, 1993. 135p. Tese (Phd.) - University of Minesota.

The wage rate estimation using the Heckman Procedure. Revista de Econometria, v. 14, n. 1, p. 89-107, abr-set. 1994.

Retornos à escolaridade e treinamento nos setores rurais e urbanos do Brasil. In: Congresso Brasileiro de Economia e Sociologia Rural, 34., Aracajú, 1996. Anais. Brasília: SOBER, 1996. v. 1, p. 771-785.

Men and women in the formal and informal labor markets in Brazil. 1997. 28 p. (no prelo).

LAM, D; LEVISON, D. Idade, experiência e diferenciais de renda: Estados Unidos e Brasil. Pesquisa e Planejamento Econômico, v. 20, n. 2, p. 219-256, ago. 1990.

LAM, D.; SCHOENI, R. F. Effects of family background on earnings and returns to Schooling: evidence from Brazil. Journal of Political Economy, v. 41, n. 101, p. 710-739, August 1993 
LANGONI, C. G. As causas do crescimento econômico no Brasil. Rio de Janeiro: APEC, 1974. 169 p.

LAU, L. J.; JAMISON, D. T.; LIN, S.; RIVIKIN, S. Education and economic growth: some cross-sectional evidence from brazil. Journal of Development Economics, v. 41, n. 1, p. 45-70, June 1993.

LEAL, C. I. S.; WERLANG, S. R. da C. Retornos em educação no Brasil: 1967-89. Pesquisa e Planejamento Econômico. Rio de Janeiro. v. 21, n. 3, p. 559-574. dez. 1991.

LEE, L. F. Generalized econometric models with selectivity. Econometrica, v.51, n.2, p.507-512, March 1983.

LOVELL, P. A. Raça, classe, gênero e discriminação salarial no Brasil. In: Estudos Afro-Asiáticos. n. 22, p. 85-98, set. 1992

LUCAS, R. E. On the mechanics of economic development. Journal of Monetary Economics, v. 22, p. 3-42, 1988

MACEDO, P. B. R. Escolaridade, experiência e salários: uma análise do setor de processamento eletrônico de dados no Brasil. Rio de Janeiro, 1982. 181 p. Dissertação (Mestrado) - Escola de Pós-Graduação em Economia, Fundação Getúlio Vargas.

MACEDO, R. B. Diferenciais de salários entre empresas privadas e estatais. Revista Brasileira de Economia. Rio de Janeiro. v. 39, n. 4, p. 437-448. out/ dez. 1985. 
MEDEIROS, J. A. S. Alcance e limitações da teoria do Capital Humano: diferença dos ganhos em 1973. São Paulo: IPE, 1982. 187 p.

MINCER, J. B. Schooling, experience and earnings. New York: NBER, 1974. 152 p.

MYINT, H. Educação e desenvolvimento: um balanço teórico. In: PEREIRA, L. Desenvolvimento, trabalho e educação. Rio de Janeiro: Zahar., 1967. p. 130-147.

PSACHAROPOULOS, G. Returns in education: a further international update and implications. Journal of Human Resources, v. 20, n. 4, p. 583-604, fall 1985.

PSACHAROPOULOS, G; VELEZ, E. Schooling and earnings in Colombia, 1988. Economic Development and Cultural Change, v. 40, n. 1, p. 629-643, April 1992.

RAMOS, L. Educação, desigualdade de renda e ciclo econômico no Brasil. Rio de Janeiro: IPEA, 1991 (Texto para discussão, 219).

RAMOS, L.; SOARES, A. L. Participação da mulher na força de trabalho e pobreza no Brasil. Revista de Economia Política, v. 15, n. 3 (59), p. 84-96, jul-set. 1995.

RAMOS, L.; VIEIRA, M. L. A relação entre educação e salários no Brasil. In: A economia brasileira em perspectiva. Rio de Janeiro: IPEA, 1996, v. 2, p. 493-510.

RAM, R. Level of development and rates of return to schooling: some estimates from multicountry data. Economic Development and Cultural Change. v. 44, n. 4 , p. 839-857, July 1996.

Relatório sobre o desenvolvimento humano no Brasil. Rio de Janeiro, 1996. 
Relatório sobre o desenvolvimento mundial. O trabalhador e o processo de integração mundial. Banco Mundial. Washington DC. 1995.

ROMER, P. M. Endogenous thecnological change. Journal of Political Economy, v. 98, p. 71-102, 1990.

ROSE, S. Distinguished fellow: Mincering labor economics. The Journal of Economic Perspectives, v. 6, n. 2, p. 157-170, spring 1992.

SACHS, J. D.; LARRAIN, F. Macroeconomia. São Paulo: Makron Books, 1995. 903 p.

SAHN, D. E.; ALDERMAN, H. The efects of human capitan on wages, and the determinants of labor suply in a developing country. Journal of Development Economics, v. 29, n. 2, p. 45-70, September 1988.

SCHUH, G. E.; BRANDÃO, A. S. P. The theory, empirical evidence, and debate on agricultural development issues in Latin America: A Selective Survey. In: AAEA - A Survey of Agricultural Economics Literature, 1990. (mimeo).

SCHULTZ, T. W. O Capital Humano: Investimentos em Educação e Pesquisa, Rio de Janeiro: Zahar, 1973. 250 p.

SCHULTZ, T. W. Investment in Human Capital. American Economic Review. v. 51, March 1961

SEDLACEK, G. L.; SANTOS, E. C. A mulher cônjuge no mercado de trabalho como estratégia de geração da renda familiar. Pesquisa e Planejamento Econômico, v. 21, n. 3, p. 449-470, dez. 1991. 
SENNA, J. J. Escolaridade, experiência no trabalho e salários no Brasil. Revista Brasileira de Economia. v. 30, n. 2, p. 163-194, abr-jun. 1976.

SHEEHAN, J. Economia da educação. Zahar, Rio de Janeiro. 1975. 178 p.

TIEFENTHALER, J. Female labor force participation and wage determination in Brasil. In Cases Studies on Women's Employment and Pay in Latin America, ed. G. Psacharoupoulos and Z. Tzannatos. 1989.

URANI, A. Ajuste macroeconômico e flexibilidade do mercado de trabalho no Brasil - 1981-1985. Rio de Janeiro: IPEA, 1996 (Texto para discussão, 380).

VALLE SILVA, N. O preço da cor: diferenciais raciais na distribuição de renda no Brasil. Pesquisa e Planejamento Econômico, v. 10, n. 1, p. 21-44, dez. 1979.

VELOSO, J. R. Educação e desigualdade de renda urbana no Brasil: 1960/80. Pesquisa e Planejamento Econômico, v. 9, n. 3, p. 661-718, dez. 1979.

VERGARA, D. H.; WILTGEN, R.S. Os diferenciais de salários entre o setor público e o setor privado na RMPA. Indicadores econômicos, v. 23, n. 3, p. 255-270, nov. 1995.

VIEIRA, N. D. Mercado de trabalho formal e informal: uma análise da discriminação e segmentação. Piracicaba, 1997. 122p. Dissertação (Mestrado) Escola Superior de Agricultura Luiz de Queiroz, Universidade de São Paulo.

WILLIAMSON, O. E. Comparative economic organization: the analysis of discrete structural alternatives. Administrative Science Quartely, n. 36, p. 269-296, june 1991. 
WILLIS, R. J. Wage Determinants: A survey and reinterpretation of human capital. In: Ashenfelter, O.; Layard, R. (Eds.), Handbook of Labor Economics. Netherlands. Elsevier Science Publishers. v. 1. 1986. 
ANEXOS 


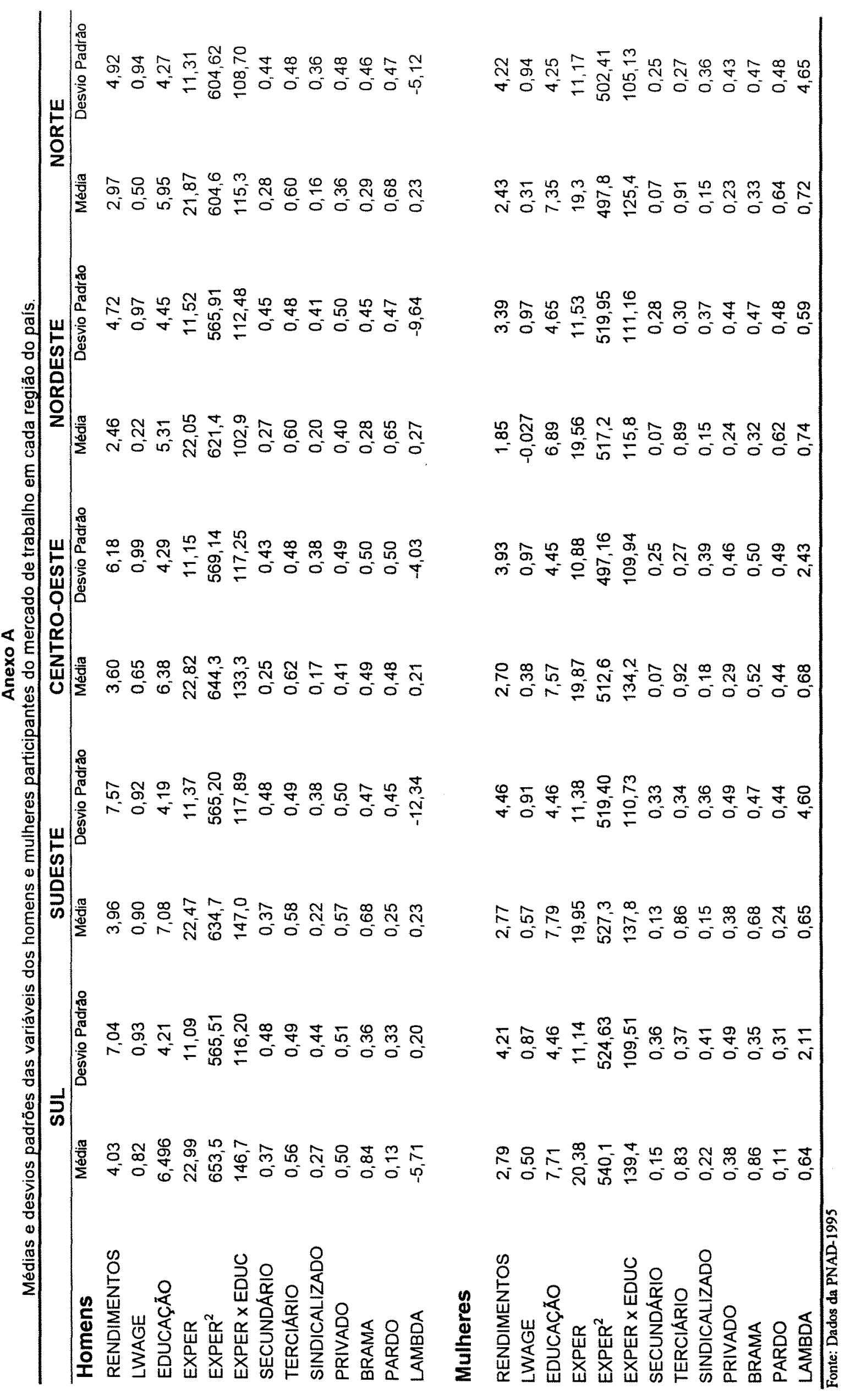




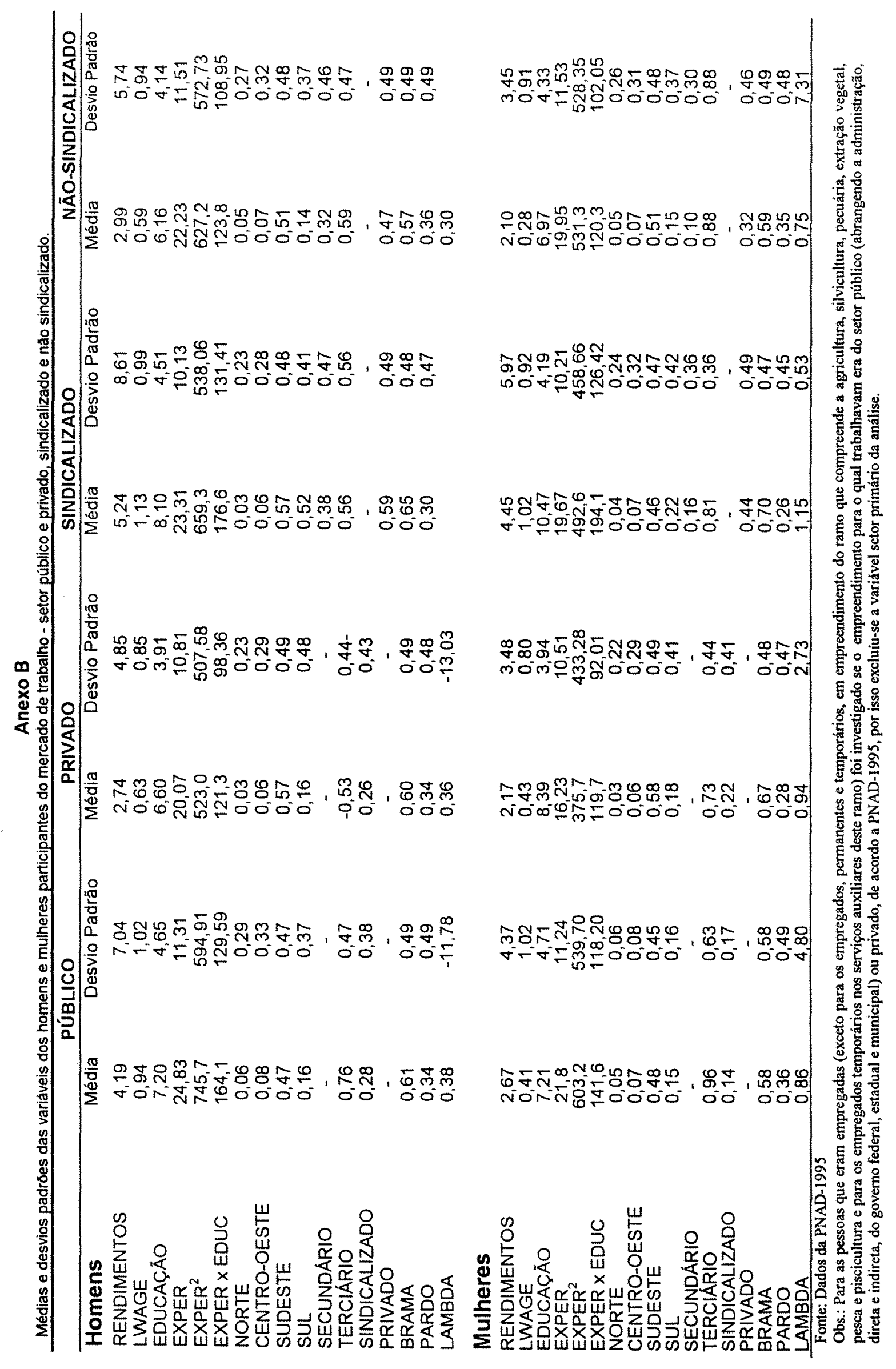




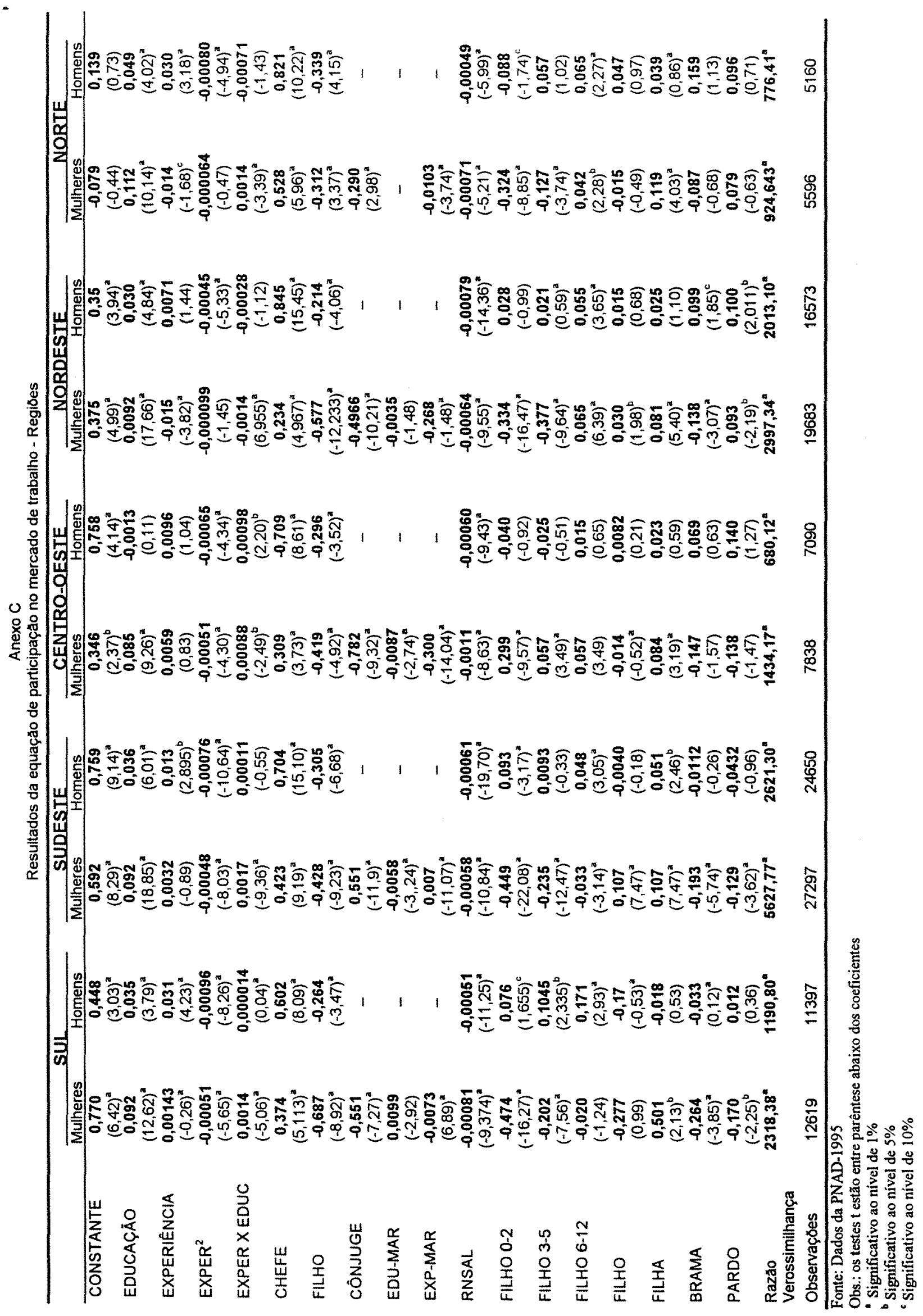




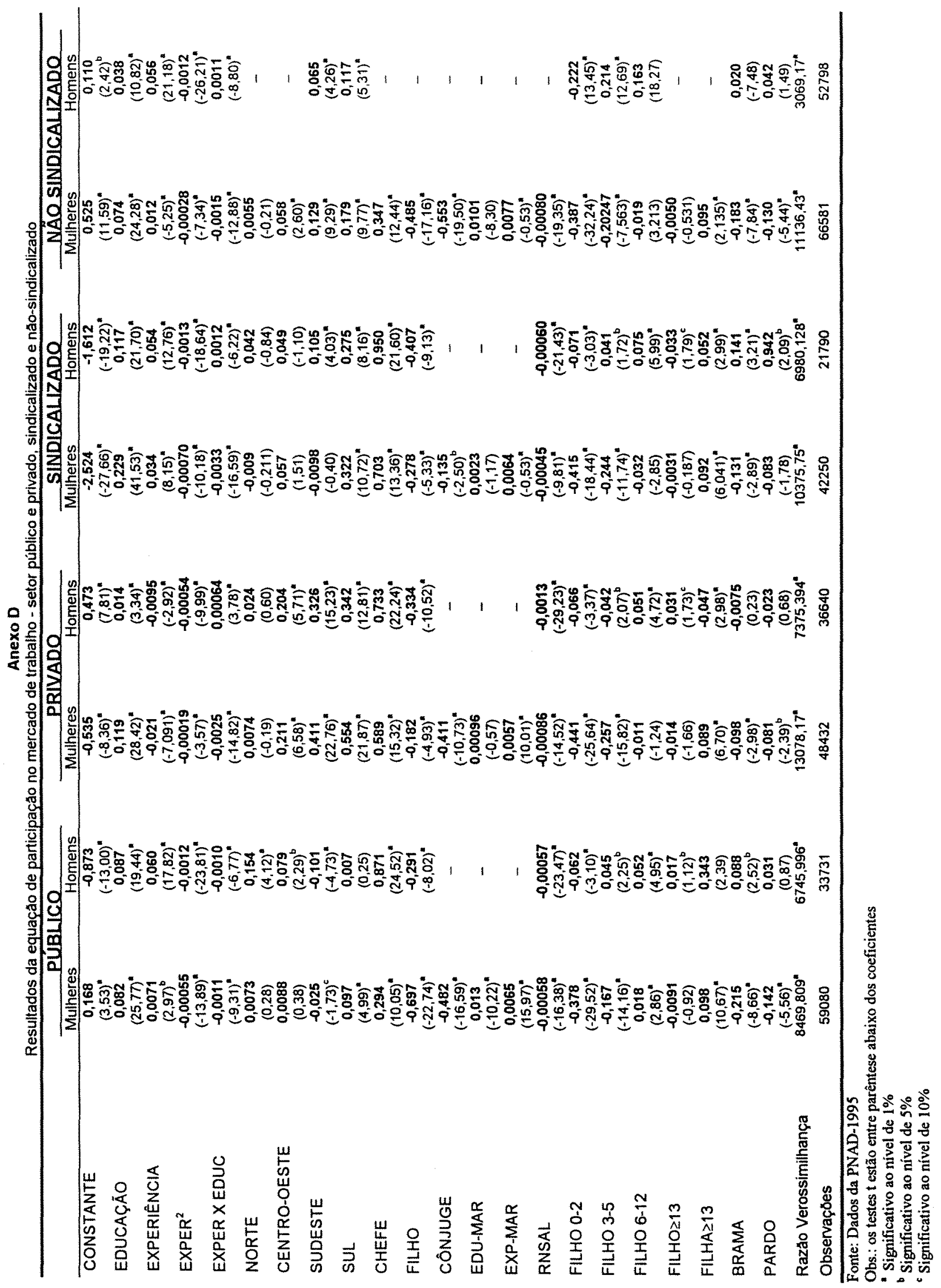




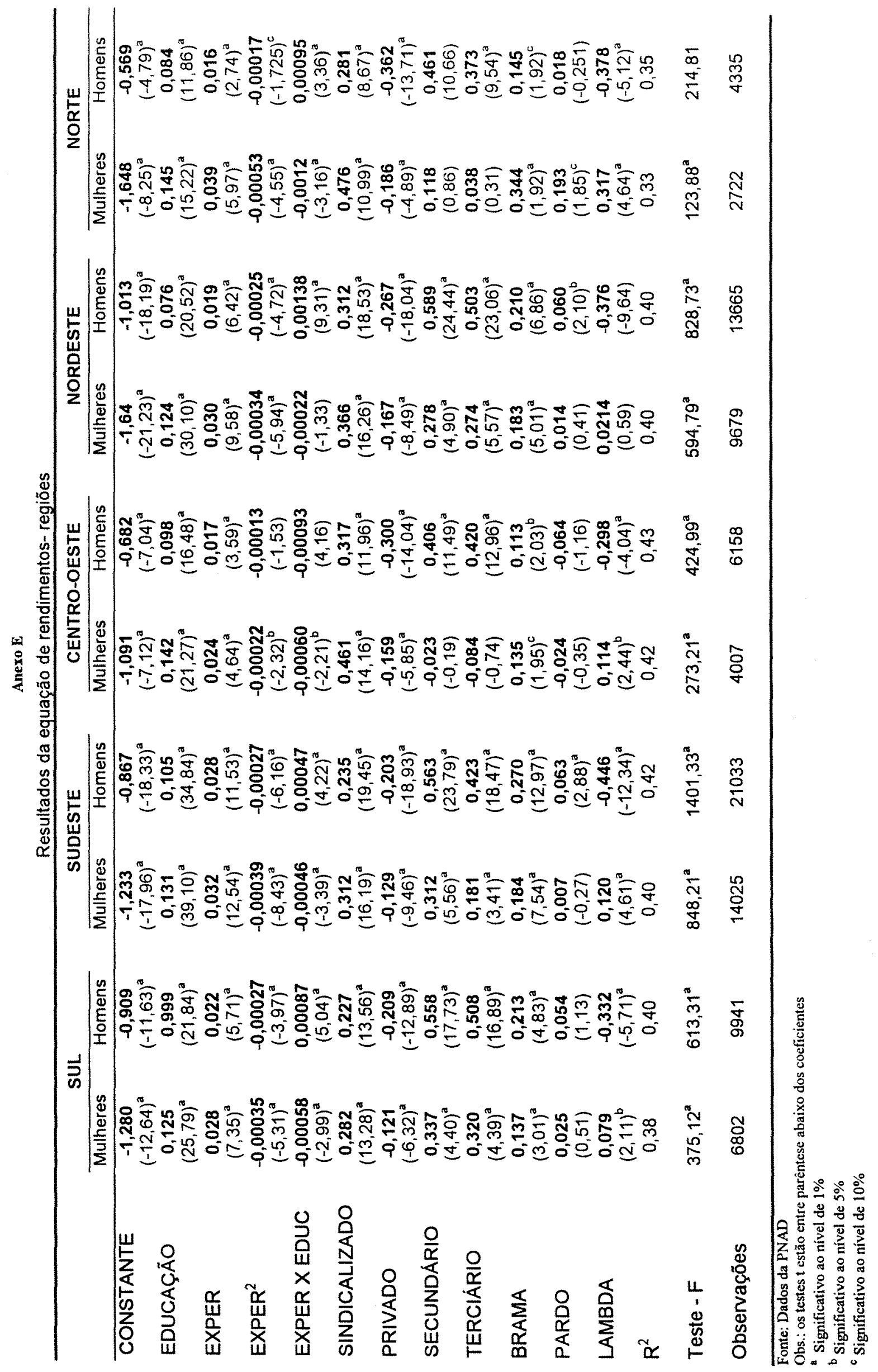




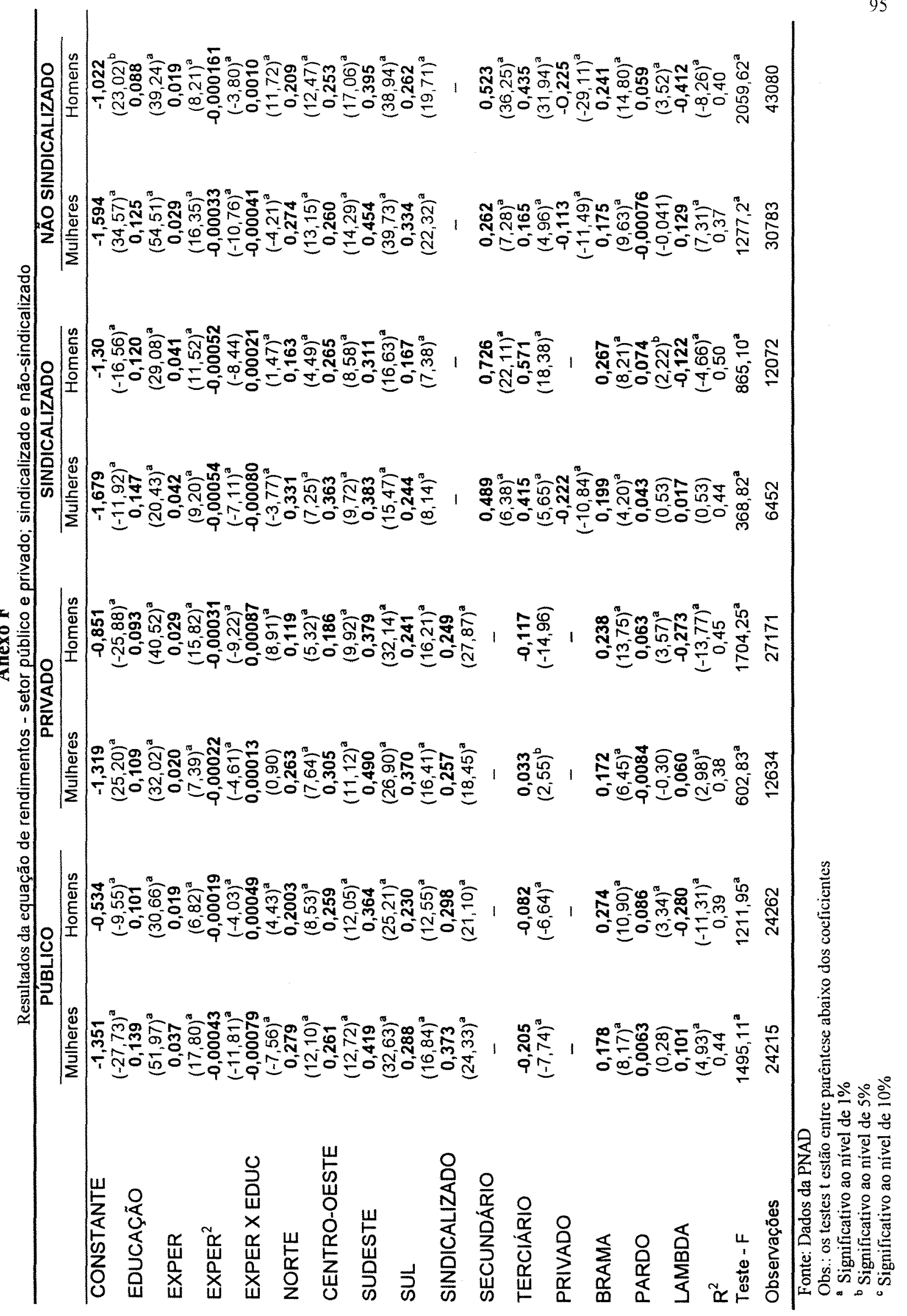




\section{Anexo G}

Os ramos de atividade foram agregados, da seguinte maneira:

\section{PRIMÁRIO}

\section{Agrícola}

Agricultura, silvicultura e pecuária

Extração vegetal

Pesca e piscicultura

\section{SECUNDÁRIO}

Indústria de Transformação

Indústria de Construção

Outras Atividades Industriais

Extração mineral

Serviços industriais de utilidade pública

\section{TERCIÁRIO}

\section{COMÉRCIO DE MERCADORIAS}

\section{PRESTAÇÃO DE SERVIÇOS}

Serviços de alojamento e alimentação

Serviços de reparação e conservação

Serviços pessoais

Serviços domiciliares

Serviços de diversões, radiodifusão e televisão

Serviços Auxiliares das Atividades Econômicas 
Serviços técnico-profissionais

Serviços auxiliares das atividades econômicas

Transporte e Comunicação

SOCIAL

Serviços comunitários e sociais

Serviços médicos, odontológicos e veterinários

Ensino

\section{ADMINISTRAÇÃO PÚBLICA}

Administração pública

Defesa nacional e segurança pública

Outras Atividades, Atividades mal definidas ou não declaradas

Instituições de crédito, de seguros e de capitalização

Comércio e administração de imóveis e valores mobiliários

Organizações internacionais e representações estrangeiras

Atividades não compreendidas nos demais ramos, atividades mal definidas ou não declaradas 